STUDI EMPIRIS FAKTOR-FAKTOR YANG MEMPENGARUHI PENGUNGKAPAN SOSIAL DAN LINGKUNGAN PERUSAHAAN MANUFAKTUR DENGAN MEKANISME CORPORATE GOVERNANCE SEBAGAI VARIABEL PEMODERASI

\author{
KARYA JURNAL ILMIAH
}

Untuk memenuhi sebagian persyaratan mencapai

Gelar Magister pada Program Studi Magister Akuntansi

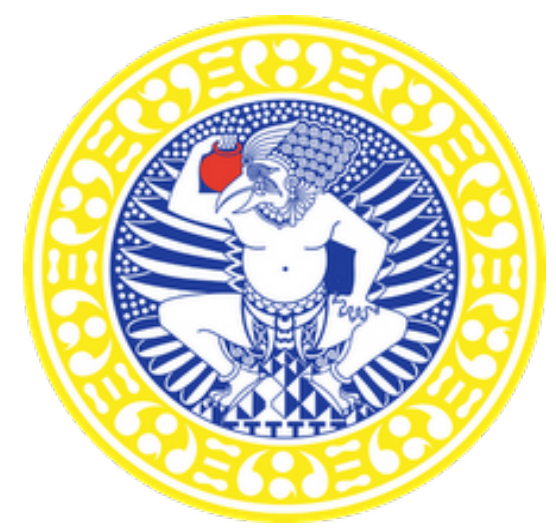

PUTU SUKMA KURNIAWAN

NIM 041214253029

Program Studi Magister Akuntansi

Pascasarjana Fakultas Ekonomi dan Bisnis

Universitas Airlangga 
Jurnal ilmiah ini telah disetujui

Surabaya, 29 Mei 2014

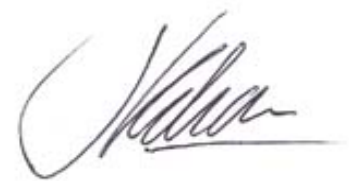

Dosen Pembimbing

Dr. Ardianto, SE., M.Si., Ak. 


\title{
STUDI EMPIRIS FAKTOR-FAKTOR YANG MEMPENGARUHI PENGUNGKAPAN SOSIAL DAN LINGKUNGAN PERUSAHAAN MANUFAKTUR DENGAN MEKANISME CORPORATE GOVERNANCE SEBAGAI VARIABEL PEMODERASI
}

\author{
Putu Sukma Kurniawan \\ putusukma1989@gmail.com \\ Ardianto \\ Universitas Airlangga
}

\begin{abstract}
Abstrak
Tujuan penelitian ini adalah untuk mengetahui pengaruh profitabilitas perusahaan, struktur modal perusahaan, ukuran perusahaan, dan manajemen laba terhadap pengungkapan sosial dan lingkungan perusahaan pada perusahaan manufaktur yang terdaftar di Bursa Efek Indonesia dan melihat peran mekanisme corporate governance sebagai variabel pemoderasi dalam pengaruh tersebut.

Populasi dalam penelitian ini sebanyak 74 perusahaan. Periode pengamatan dimulai pada tahun 2008-2012. Pengukuran mekanisme corporate governance menggunakan analisis faktor. Metode statistik yang digunakan adalah analisis regresi moderasi (MRA).

Hasil penelitian menunjukkan bahwa profitabilitas perusahaan dan ukuran perusahaan berpengaruh positif terhadap pengungkapan sosial dan lingkungan perusahaan, struktur modal perusahaan berpengaruh negatif terhadap pengungkapan sosial dan lingkungan perusahaan, dan manajemen laba tidak berpengaruh terhadap pengungkapan sosial dan lingkungan perusahaan. Penelitian ini menunjukkan bahwa mekanisme corporate governance sebagai variabel moderasi tidak mampu memperkuat pengaruh profitabilitas perusahaan, struktur modal perusahaan, ukuran perusahaan, dan manajemen laba terhadap pengungkapan sosial dan lingkungan perusahaan.
\end{abstract}

Kata kunci: profitabilitas perusahaan, struktur modal perusahaan, ukuran perusahaan, manajemen laba, mekanisme corporate governance, pengungkapan sosial dan lingkungan perusahaan

\section{PENDAHULUAN}

\subsection{Latar Belakang Masalah}

Saat ini konsep bisnis yang harus dijalankan oleh perusahaan mengalami perubahan seiring dengan adanya tuntutan bagi perusahaan untuk melaksanakan tanggung jawab sosial dan lingkungan. Kegiatan bisnis yang harus dilaksanakan perusahaan harus juga memikirkan dampaknya terhadap kondisi sosial dan lingkungan yang ada di sekitar perusahaan. Perusahaan saat ini tidak hanya dituntut untuk memikirkan kepentingan manajemen, investor, dan kreditur saja, tetapi perusahaan juga harus memikirkan kepentingan komunitas sosial yang berada di luar perusahaan. Hal ini dikarenakan aktivitas-aktivitas produksi dan distribusi dalam perusahaan selalu melibatkan unsur-unsur sosial (Choi dan Mueller, 1998). Unsurunsur sosial tersebut misalnya karyawan, konsumen, pemerintah, dan termasuk juga lingkungan hidup. Adanya unsur-unsur sosial dan lingkungan dalam aktivitas perusahaan ini mengakibatkan perusahaan memiliki tanggung jawab sosial terhadap pihak-pihak di luar manajemen dan pemilik modal (Choi dan Mueller, 1998). 
Tanggung jawab sosial dan lingkungan perusahaan harus berpijak pada triple bottom lines (economic prosperity, environmental quality, dan social justice) yaitu tanggung jawab perusahaan pada aspek tujuan ekonomi, aspek kualitas lingkungan, dan aspek keadilan sosial sehingga setiap perusahaan diwajibkan mengungkapkan informasi tentang tanggung jawab sosial perusahaan atau corporate social responsibility (CSR) (Puspitasari, 2008). Perusahaan tidak hanya dituntut untuk mengejar keuntungan (profit) saja, tetapi juga memperhatikan dan terlibat pada pemenuhan kesejahteraan masyarakat (people) dan ikut memelihara dan menjaga kelestarian lingkungan (planet). Nuryaman (2013) menjelaskan secara lebih spesifik bahwa people dalam kegiatan sosial perusahaan berarti bahwa entitas bisnis harus bertanggung jawab terhadap kesejahteraan sosial (social welfare) stakeholders perusahaan, profit diartikan bahwa perusahaan tidak hanya mengejar keuntungan demi kepentingan perusahaan saja namun juga harus dapat menyalurkan kemajuan ekonomi kepada stakeholders perusahaan, dan planet diartikan bahwa perusahaan harus bijak dalam menggunakan sumber daya alam dalam aktivitas perusahaan dan meminimalisasi produksi limbah yang dapat mencemari lingkungan. Almilia et al. (2011) mendukung adanya kepedulian sosial dan lingkungan perusahaan karena keberlanjutan perusahaan (corporate sustainability) hanya akan terjamin bila perusahaan memperhatikan dimensi sosial dan lingkungan hidup yang berada di luar perusahaan. Arshad et al. (2012) berpendapat bahwa peningkatan kepedulian peran bisnis terhadap komunitas sosial dan sifat dari tanggung jawab sosial perusahaan telah menimbulkan permintaan baik secara sosial maupun politis kepada perusahaan agar meningkatkan aktivitas sosialnya. Lebih lanjut Sutantoputra (2009) menjelaskan bahwa perusahaan akan lebih termotivasi mengungkapkan tanggung jawab sosial dan lingkungannya jika perusahaan memiliki kinerja yang sangat baik dalam bidang sosial, lingkungan, dan ekonomi.

Dalam konteks pengelolaan perusahaan terdapat teori keagenan yang dapat memberikan pemahaman mengenai perilaku manajemen dalam mengelola perusahaan. Menurut Jensen dan Meckling (1976), teori keagenan (agency theory) menjelaskan adanya kontrak antara agent (manajemen) dan principal (pemegang saham) yang mana dalam hal ini agent menerima mandat untuk mengelola perusahaan dari principal. Adanya pemisahan antara kepemilikan perusahaan dengan pengelolaan perusahaan akan memunculkan masalah agensi dimana agent dapat saja melakukan tindakan yang tidak sejalan dengan keinginan principal. Untuk mengatasi masalah ini maka muncul konsep tata kelola perusahaan yang baik atau good corporate governance. Konsep corporate governance merupakan konsep pengelolaan perusahaan yang terdiri atas sekumpulan mekanisme yang saling berkaitan di mana terdiri atas pemegang saham institusional, dewan direksi dan komisaris, para manajer yang dibayar berdasarkan kinerja, pasar modal sebagai pengendali saham perseroan, struktur kepemilikan, struktur keuangan, dan investor terkait. Mekanisme corporate governance meliputi mekanisme memperbesar kepemilikan saham oleh institusional, mekanisme memperbesar kepemilikan saham perusahaan oleh manajemen (manajerial ownership), mekanisme peran monitoring oleh dewan komisaris independen, serta mekanisme keberadaan komite audit (Setyarini dan Purwanti, 2011).

Teori keagenan memandang bahwa manajemen sebagai pihak yang menjalankan secara penuh operasi perusahaan tidak dapat dipercaya untuk bertindak sebaik mungkin bagi kepentingan para pemegang saham yang biasa disebut dengan agency conflict. Salah satu cara untuk mengurangi agency conflict adalah dengan cara meningkatkan persentase atau level kepemilikan manajemen terhadap perusahaan. Hal ini dikarenakan jika semakin besar kepemilikan saham oleh manajer maka akan semakin mengurangi perilaku oportunistik manajer untuk memaksimalkan kepentingan pribadi. Dengan begitu manajer akan mengambil keputusan sesuai dengan kepentingan perusahaan, yaitu salah satunya dengan mengungkapkan informasi CSR utuk meningkatkan image perusahaan (Wahyuningtyas dan 
Nugrahanti, 2010). Cormier et al. (2009) berpendapat bahwa pengungkapan sosial yang dilakukan oleh manajemen perusahaan dapat mengurangi biaya modal perusahaan.

Berdasarkan hasil-hasil penelitian terdahulu, misalnya penelitian Jamali et al. (2008) yang meneliti mengenai hubungan corporate governance dengan kegiatan sosial perusahaan dan pengungkapannya dan pendapat Utama (2011) yang berpendapat bahwa mekanisme dan struktur corporate governance merupakan salah satu pendukung pengungkapan sosial perusahaan, maka dapat dikatakan bahwa mekanisme corporate governance merupakan salah satu infrastruktur pendukung terjadinya pengungkapan sosial dan lingkungan yang dilakukan oleh manajemen perusahaan. Survey yang dilakukan KPMG menunjukkan bahwa 80\% dari perusahaan global dalam Fortune 250 (G250) mengungkapkan mengenai aktivitas sosialnya dan $45 \%$ dari 100 perusahaan terbesar di dunia yang disurvey di 22 negara mengeluarkan laporan mengenai aktivitas sosial perusahaannya (Jones dan Jonas, 2011). Hal ini menunjukkan bahwa secara global, manajemen perusahaan sudah mulai memperhatikan mengenai pengungkapan aktivitas sosial dan lingkungan yang harus dilakukan oleh perusahaan.

Setyorini dan Ishak (2012) dalam penelitiannya memandang corporate social and environmental disclosure dari sudut pandang teori akuntansi positif (TAP). Setyorini dan Ishak (2012) berpendapat bahwa faktor-faktor yang dapat mempengaruhi pengungkapan sosial dan lingkungan perusahaan adalah profitabilitas perusahaan, struktur modal perusahaan, ukuran perusahaan, dan manajemen laba. Seorang manajer dari sebuah perusahaan yang memiliki rencana bonus akan cenderung menggunakan metode akuntansi yang meningkatkan income pada periode sekarang atau seorang manajer cenderung akan memilih prosedur akuntansi yang merubah pelaporan keuntungan dari masa depan menjadi saat ini untuk meningkatkan bonusnya (Setyorini dan Ishak, 2012). Berdasarkan hasil kerja Watts dan Zimmerman (1990), penelitian yang menggunakan teori akuntansi positif secara tipikal mengadopsi baik sudut pandang efisiensi (efficiency perspective) maupun sudut pandang oportunistik (opportunistic perspective). Menurut Deegan (2007), dalam sudut pandang efisiensi, penelitian terdahulu mencoba menjelaskan bagaimana mekanisme kontrak yang beraneka ragam mampu meminimalisasi biaya agensi (agency cost) dari perusahaan kepada agen. Sudut pandang oportunistik telah dijelaskan oleh Deegan (2007) dengan mengasumsikan bahwa manajer akan secara oportunis memilih sebuah metode akuntansi khusus yang dapat meningkatkan kemakmuran mereka secara pribadi (personal wealth). Hal ini dapat menjelaskan mengapa pengungkapan sosial dan lingkungan lebih banyak dilakukan oleh perusahaan dengan kinerja yang baik dan tentu saja akan meningkatkan bonus yang didapat oleh manajer (Setyorini dan Ishak, 2012). Nurkhin (2010) mengungkapkan bahwa profitabilitas atau keuntungan perusahaan merupakan faktor yang membuat manajemen menjadi bebas dan fleksibel untuk mengungkapkan pertanggungjawaban sosial kepada pemegang saham. Perusahaan dengan tingkat profitabilitas yang tinggi akan memberikan kemudahan kepada manajemen untuk melaksanakan dan mengungkapkan CSR. Perusahaan dengan tingkat profitabilitas rendah akan sangat mempertimbangkan pelaksanaan dan pengungkapan CSR, karena khawatir akan mengganggu operasional perusahaan (Nurkhin, 2010). Dalam penelitian terdahulu yang terkait dengan pengungkapan sosial dan lingkungan perusahaan, beberapa penelitian menemukan korelasi yang positif antara rencana bonus atau profitabilitas dengan pengungkapan sosial dan lingkungan. Contohnya Chan dan Kent (2003) yang meneliti mengenai hubungan antara $R O E$ dan pengungkapan sosial dan menemukan bahwa hubungannya adalah positif. Penelitian Barako et al. (2006) menggunakan ROA sebagai proxy dari hipotesis rencana bonus.

Perusahaan dengan rasio hutang/modal yang tinggi membuat manajer cenderung menggunakan metode akuntansi yang dapat meningkatkan income (Setyorini dan Ishak, 2012). Dengan rasio hutang/modal yang tinggi ini, manajer akan memilih metode akuntansi 
yang menggeser keuntungan pada masa depan menjadi keuntungan pada periode sekarang. Perilaku manajer ini juga menjadi argumentasi bahwa perusahaan dengan rasio hutang/modal yang tinggi mendapatkan monitoring atau pengawasan yang lebih ketat dari pihak pemegang saham dan kreditur. Pengawasan yang ketat dari pemegang saham dan kreditur merupakan permasalahan tersendiri yang harus dihadapi oleh perusahaan. Alarussi et al. (2009) menjelaskan bahwa untuk mengatasi permasalahan pengawasan yang ketat ini, perusahaan akan meningkatkan tingkat dari pengungkapan sosial seperti hasil penelitian yang telah dilakukan di Malaysia. Jensen \& Meckling (1976) menjelaskan teori keagenan yang mengatakan bahwa perusahaan dengan rasio leverage yang lebih tinggi akan mengungkapkan lebih banyak informasi karena biaya keagenan perusahaan dengan struktur modal seperti itu lebih tinggi. Tambahan informasi diperlukan untuk memenuhi hak-hak dari kreditur. Hal ini akan membuat perusahaan dengan rasio leverage yang tinggi memiliki kewajiban untuk melakukan pengungkapan yang lebih luas daripada perusahaan dengan rasio leverage yang rendah.

Perusahaan-perusahaan besar juga akan cenderung menggunakan metode akuntansi yang mengurangi keuntungan yang dilaporkan pada periode saat ini untuk mengurangi biayabiaya politik yang timbul. Ukuran perusahaan (size), capital intensity, dan market share merupakan beberapa proxy yang dipergunakan untuk menentukan biaya politik (Setyorini dan Ishak, 2012). Perusahaan-perusahaan besar juga cenderung lebih sensitif secara politik dibandingkan perusahaan-perusahaan yang kecil dan menghadapi insentif yang berbeda terkait dengan pemilihan prosedur akuntansi. Manajer dalam konteks biaya politik akan beranggapan bahwa mereka berada dalam suatu kontrak (great deal of political) dari komunitas sosial dan tekanan dari publik, yang mungkin saja hal ini dapat memotivasi manajer untuk melakukan pengungkapan sosial dan lingkungan (Setyorini dan Ishak, 2012).

Penelitian ini akan membahas bagaimana pengaruh profitabilitas perusahaan yang diproksikan dengan return on assets, struktur modal perusahaan yang diproksikan dengan leverage, ukuran perusahaan, dan manajemen laba terhadap pengungkapan sosial dan lingkungan perusahaan dengan mekanisme corporate governance sebagai variabel moderasi. Dalam banyak literatur ilmiah, misalnya Utama (2011), mekanisme corporate governance dikatakan merupakan salah satu infrastruktur pendukung terjadinya pengungkapan sosial dan lingkungan yang dilakukan oleh perusahaan sehingga menarik untuk diteliti bagaimana pengaruh mekanisme corporate governance apakah dapat memperkuat pengaruh antara profitabilitas perusahaan, struktur modal perusahaan, ukuran perusahaan, dan manajemen laba terhadap pengungkapan sosial dan lingkungan perusahaan. Variabel independen dalam penelitian ini didasarkan pada variabel independen yang dipergunakan pada penelitian Setyorini dan Ishak (2012). Pemilihan variabel independen juga didasarkan pada penelitian Othman dan Ameer (2009) yang melakukan penelitian studi literatur terhadap penelitianpenelitian terdahulu yang membahas mengenai pengungkapan sosial dan lingkungan perusahaan. Othman dan Ameer (2009) secara umum menemukan bahwa faktor-faktor yang dapat mempengaruhi pengungkapan sosial dan lingkungan perusahaan adalah industry, size, profit, growth opportunities, leverage, cross listing, culture, dan corporate governance.

Alasan penelitian ini menggunakan perusahaan manufaktur karena manufaktur merupakan tipe industri yang relatif lebih banyak memiliki dampak pada lingkungan dibandingkan tipe industri lainnya dan aktivitas operasional perusahaan manufaktur sangat terkait dengan lingkungan dan masyarakat. Perusahaan manufaktur juga diasumsikan memiliki kontribusi yang besar terhadap kemungkinan adanya pencemaran lingkungan, misalnya pencemaran air, pencemaran udara, dan pencemaran tanah, serta adanya kerusakan lingkungan akibat limbah atau polusi yang dihasilkan. Beberapa alasan ini dapat menguatkan asumsi bahwa perusahaan-perusahaan manufaktur akan lebih banyak melakukan pengungkapan mengenai informasi sosial dan lingkungan. 


\subsection{Perumusan Masalah}

Berdasarkan latar belakang masalah yang telah diuraikan diatas, maka rumusan masalah yang dapat digunakan dalam penelitian ini adalah :

1. Apakah terdapat pengaruh antara profitabilitas perusahaan, struktur modal perusahaan, ukuran perusahaan, dan manajemen laba terhadap pengungkapan sosial dan lingkungan perusahaan pada perusahaan manufaktur yang terdaftar di Bursa Efek Indonesia?

2. Apakah mekanisme corporate governance dapat memperkuat pengaruh profitabilitas perusahaan, struktur modal perusahaan, ukuran perusahaan, manajemen laba terhadap pengungkapan sosial dan lingkungan perusahaan pada perusahaan manufaktur yang terdaftar di Bursa Efek Indonesia?

\section{TINJAUAN PUSTAKA}

2.1. Teori keagenan (agency theory)

Teori agensi berpendapat bahwa semua individu dalam perusahaan bertindak untuk kepentingan mereka sendiri. Pemegang saham sebagai principal diasumsikan hanya tertarik kepada hasil keuangan atau investasi mereka yang bertambah di dalam perusahaan, sedangkan manajer sebagai agent diasumsikan menerima kepuasan berupa kompensasi keuangan dan syarat-syarat yang menyertai dalam kontrak dengan principal (Terzaghi, 2012). Salah satu hipotesis dalam teori ini adalah manajemen dalam melakukan pengelolaan perusahaan cenderung lebih mementingkan kepentingan atau utilitas pribadinya daripada meningkatkan nilai perusahaan yang dikelola sehingga hal ini mengakibatkan konflik kepentingan antara principal dan agent di atas hubungan yang kooperatif (Terzaghi, 2012).

\subsection{Teori legitimasi}

Teori lain yang dapat dipergunakan untuk menjelaskan pengungkapan sosial dan lingkungan yang dilakukan perusahaan adalah teori legitimasi. Teori legitimasi berpendapat bahwa sistem pengelolaan perusahaan harus berorientasi pada keberpihakan terhadap masyarakat (society), kelompok masyarakat, dan lingkungan (Retno dan Priantinah, 2012). Teori legitimasi menyarankan kepada perusahaan untuk memastikan bahwa operasional perusahaan sesuai dengan norma sosial yang ada di lingkungan perusahaan (Laan, 2009).

\subsection{Teori stakeholder}

Teori stakeholder berpendapat bahwa perusahaan bukanlah entitas yang hanya berdiri sendiri dan beroperasi hanya untuk kepentingannya sendiri namun perusahaan harus memberikan manfaat bagi stakeholders yang ada di lingkungan perusahaan (Terzaghi, 2012). Teori stakeholder mengasumsikan bahwa eksistensi perusahaan ditentukan oleh para stakeholders (Indrawati, 2009). Manajemen perusahaan berupaya untuk mencari pembenaran dari sudut pandang stakeholders dalam menjalankan operasional perusahaan. Semakin kuat posisi stakeholders yang berada di luar perusahaan, maka semakin kuat pula kecenderungan manajemen perusahaan untuk berupaya beradaptasi agar sesuai dengan keinginan stakeholders. Jika perusahaan tidak memperhatikan stakeholders yang ada, maka dapat mengeliminasi legitimasi perusahaan di mata stakeholders (Retno dan Priantinah, 2012).

\subsection{Manajemen laba}

Manajemen laba dapat didefinisikan sebagai “intervensi atau pengaruh manajemen dengan sengaja dalam proses penentuan laba dan umumnya dipergunakan untuk memenuhi utilitas manajemen” (Schipper, 1989). Menurut Soetedjo (2009), manajemen laba adalah pilihan kebijakan akuntansi oleh seorang manajer untuk mencapai beberapa tujuan tertentu. 
Manajemen laba dapat dipandang dari sisi penyusunan kontrak maupun pelaporan keuangan (Soetedjo, 2009).

Dari sisi pelaporan keuangan, manajer dapat menggunakan manajemen laba untuk menyesuaikan estimasi pendapatan yang dikemukakan oleh para analis, dan karenanya menghindari reaksi harga saham yang negatif yang segera mengikuti kegagalam memenuhi harapan investor. Hal ini mengakibatkan manajemen laba banyak digunakan untuk mempercantik angka di laporan keuangan dan umumnya untuk mempercantik angka laba (Subramanyam dan Wild, 2008). Manajemen laba merupakan hasil dari kebebasan dalam aplikasi akuntansi akrual yang mungkin terjadi. Standar akuntansi yang ada dan mekanisme pengawasan yang dilakukan mungkin dapat mengurangi praktek manajemen laba ini. Meskipun terdapat standar akuntansi yang baik dan mekanisme pengawasan meningkat, manajemen laba tidak mungkin untuk dihilangkan karena kompleksitas dan keragaman aktivitas usaha. Manajemen laba juga muncul akibat akuntansi akrual yang membutuhkan estimasi dan penilaian dari manajemen (Subramanyam dan Wild, 2008). Tujuan manajemen laba adalah untuk menyesatkan stakeholders tentang kinerja ekonomi perusahaan (Lasdi, 2008). Tindakan manajemen untuk melakukan manajemen laba dapat menyesatkan dan dapat menyebabkan pihak outsider atau pengguna laporan keuangan membuat keputusan ekonomi yang salah.

\subsection{Asas corporate governance}

Menurut Zarkasyi (2008) terdapat beberapa asas dalam corporate governance. Asasasas tersebut antara lain:

1. Transparansi

2. Akuntabilitas

3. Responsibilitas

4. Independensi

5. Kewajaran dan kesetaraan

\subsection{Implementasi corporate governace}

Konsep corporate governance menjadi isu yang penting di pasar modal di seluruh dunia semenjak adanya krisis-krisis keuangan yang terjadi. Konsep ini berkembang cepat semenjak adanya penurunan pasar keuangan di Asia dan Amerika Serikat pada awal tahun 2000, krisis keuangan global pada tahun 2008, dan krisis hutang yang terjadi pada negaranegara di Eropa pada tahun 2010-2011 (Palepu dan Healy, 2013). Adanya krisis keuangan dan krisis pasar modal mengindikasikan dan memperlihatkan adanya permasalahan dalam transparansi pengelolaan perusahaan. Permasalahan ini dapat terjadi akibat adanya kesalahan dalam tata kelola perusahaan dan konflik kepentingan yang terjadi dalam proses monitoring kinerja manajemen dan pengungkapan yang dilakukan perusahaan (Palepu dan Healy, 2013).

Terdapat pula hubungan antara corporate governance dengan pengungkapan sosial yang dilakukan oleh perusahaan. Pola dari konsep GCG mengalami perubahan dari konsep tradisional yang lebih mementingkan kepentingan pemegang saham menjadi konsep baru yang juga memberikan perhatian kepada semua stakeholders perusahaan (Andayani dan Atmini, 2012). Tuntutan terhadap perusahaan untuk memberikan informasi yang transparan, organisasi yang akuntabel, serta tata kelola perusahaan yang semakin bagus (good corporate governance) semakin memaksa manajemen perusahaan untuk memberikan informasi mengenai aktivitas sosialnya.

Pada Pedoman Umum Good Corporate Governance Indonesia telah dijelaskan pula mengenai prinsip dasar dalam azas responsibilitas dimana dalam pedoman pokok pelaksanaan telah dijelaskan bahwa perusahaan harus melaksanakan tanggung jawab sosial dengan antara lain peduli terhadap masyarakat dan kelestarian lingkungan terutama di sekitar 
perusahaan dengan membuat perencanaan dan pelaksanaan yang memadai (KNKG, 2006). Bahkan dalam bagian fungsi direksi, yaitu tanggung jawab sosial, KNKG (2006) dengan jelas menyatakan bahwa dalam rangka mempertahankan kesinambungan usaha perusahaan, direksi harus dapat memastikan dipenuhinya tanggung jawab sosial perusahaan dan direksi harus mempunyai perencanaan tertulis yang jelas dan fokus dalam melaksanakan tanggung jawab sosial perusahaan.

\section{HIPOTESIS}

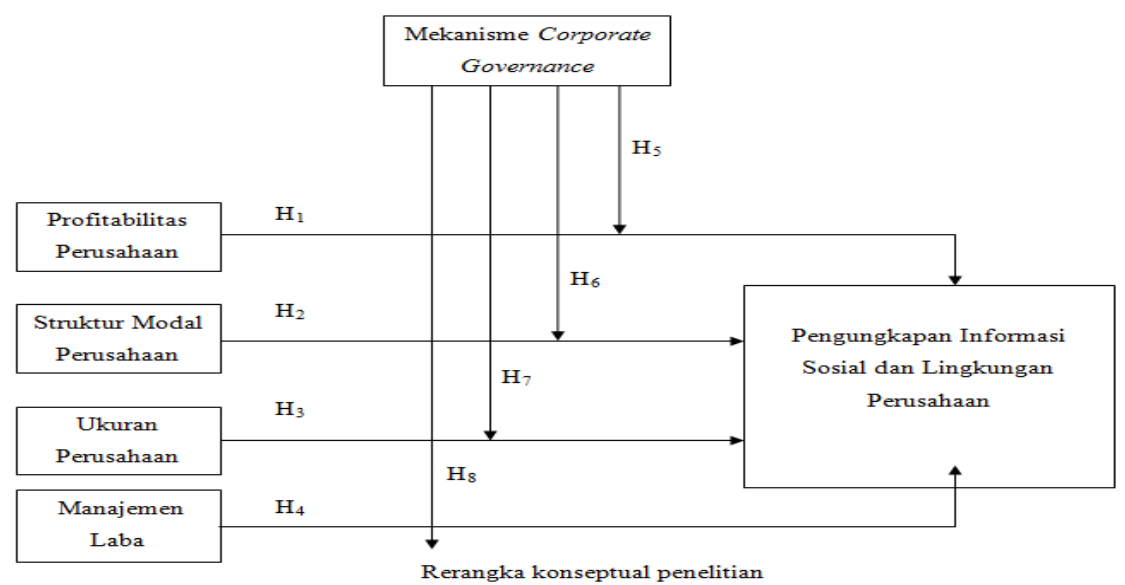

\subsection{Pengaruh Profitabilitas Perusahaan Manufaktur Terhadap Pengungkapan Sosial dan Lingkungan Perusahaan Manufaktur}

Penelitian Liu et al. (2009) meneliti mengenai hubungan antara profitabilitas dengan tingkat pengungkapan sosial yang dilakukan perusahaan. Hasil penelitian Liu et al. (2009) menyatakan bahwa perusahaan dengan kinerja keuangan yang tinggi akan cenderung untuk mengungkapkan lebih banyak aktivitas sosial dan lingkungan perusahaan. Kamil dan Herusetya (2012) berpendapat bahwa tingkat profitabilitas yang tinggi menjelaskan kemampuan perusahaan untuk menghasilkan laba yang semakin besar dan perusahaan mampu untuk meningkatkan tanggung jawab sosialnya. Semakin banyak perusahaan melakukan tanggung jawab sosial, maka manajemen akan melakukan pengungkapan tanggung jawab sosialnya secara luas dalam laporan tahunan.

Mia dan Mamun (2011) berpendapat bahwa perusahaan dengan profitabilitas yang tinggi akan cenderung menjadi perhatian publik dan aktivitas perusahaan tersebut sangat mudah menjadi perhatian masyarakat sehingga pengungkapan sosial dan lingkungan perlu dilakukan untuk meyakinkan masyarakat bahwa aktivitas perusahaan tidak terlalu berdampak terhadap komunitas sosial dan lingkungan. Setyorini dan Ishak (2012) menjelaskan bahwa berdasarkan hipotesis rencana bonus (bonus plan hypothesis), terdapat hubungan yang positif antara profitabilitas perusahaan dengan pengungkapan lingkungan perusahaan dimana ketika profitabilitas perusahaan meningkat, maka manajemen memiliki motivasi untuk memperluas pengungkapan sosial dan lingkungan perusahaan.

$\mathbf{H}_{1}=$ Profitabilitas perusahaan manufaktur berpengaruh positif terhadap pengungkapan sosial dan lingkungan perusahaan manufaktur

\subsection{Pengaruh Struktur Modal Perusahaan Manufaktur Terhadap Pengungkapan Sosial dan Lingkungan Perusahaan Manufaktur}

Manajemen dalam melakukan pengelolaan perusahaan sangat terikat dengan kontrak hutang terhadap kreditur. Manajemen dituntut untuk menjaga rasio-rasio dalam kontrak hutang, misalnya rasio leverage agar perjanjian kontrak hutang dengan kreditur tetap terjaga. 
Menjaga rasio-rasio dalam kontrak hutang ini merupakan argumentasi bahwa perusahaan dengan rasio hutang/modal yang tinggi akan mendapatkan monitoring atau pengawasan yang lebih ketat dari pihak pemegang saham dan kreditur (Setyorini dan Ishak, 2012). Penelitian Alarussi et al. (2009) menjelaskan bahwa untuk mengatasi permasalahan monitoring atau pengawasan yang ketat ini, perusahaan akan meningkatkan tingkat pengungkapan sosial dan lingkungan perusahaan. Menurut Kamil dan Herusetya (2012), perusahaan dengan rasio solvabilitas yang tinggi memiliki kewajiban untuk memenuhi kebutuhan informasi kepada kreditur jangka panjang dengan cara menyediakan informasi mengenai perusahaan secara lebih lengkap. Untuk menghilangkan keraguan kreditur, maka diperlukan adanya tambahan informasi termasuk pengungkapan tanggung jawab sosial dan lingkungan perusahaan untuk menunjukkan bahwa perusahaan memiliki peluang untuk tetap bertahan dalam industri atau going concern yang tinggi (Kamil dan Herusetya, 2012).

Pendapat lain mengungkapkan pula bahwa perusahaan dengan tingkat rasio hutang yang tinggi akan cenderung untuk mengungkapkan mengenai private information kepada krediturnya, sehingga pengungkapan sosial dan lingkungan perusahaan akan bertambah seiring dengan tingkat leverage perusahaan (Setyorini dan Ishak, 2012). Berdasarkan penelitian Christopher dan Filipovic (2008) dan Ma dan Zhao (2009), perusahaan dengan leverage yang tinggi akan cenderung untuk melakukan pengungkapan sosial dan lingkungan. Hal ini akan berimplikasi jika kreditur sangat peduli terhadap isu-isu sosial dan lingkungan, maka manajemen perusahaan akan lebih banyak mengungkapkan informasi sosial dan lingkungan perusahaan.

$\mathbf{H}_{2}=$ Struktur modal perusahaan manufaktur berpengaruh positif terhadap pengungkapan sosial dan lingkungan perusahaan manufaktur

\subsection{Pengaruh Ukuran Perusahaan Manufaktur Terhadap Pengungkapan Sosial dan Lingkungan Perusahaan Manufaktur}

Zadeh dan Eskandari (2012) berpendapat bahwa berdasarkan teori agensi, perusahaan dengan ukuran yang besar akan dimonitoring oleh lebih banyak stakeholders dan ada biaya agensi yang disebabkan oleh asimetri informasi. Manajemen perusahaan akan memerlukan upaya yang lebih besar untuk memperoleh legitimasi dari stakeholders dalam rangka menciptakan keseimbangan antara aktivitas perusahaan dengan kepentingan stakeholders di luar perusahaan, misalnya dampak sosial dan lingkungan yang dapat ditimbulkan dari aktivitas perusahaan. Lindblom (1993) berpendapat bahwa berdasarkan teori legitimasi, perusahaan dengan ukuran besar melakukan keputusan pengungkapan sosial dan lingkungan sebagai reaksi atas tekanan yang dilakukan oleh stakeholders di luar perusahaan. Hal ini mengakibatkan adanya pengaruh stakeholders terhadap jumlah dan isi dari pengungkapan sosial dan lingkungan perusahaan.

Penelitian Watson et al. (2002) menemukan bahwa perusahaan dengan ukuran yang besar tidak memerlukan biaya yang terlalu besar untuk melakukan pengungkapan sukarela dibandingkan dengan perusahaan ukuran kecil. Galani et al. (2011) berpendapat bahwa perusahaan dengan ukuran besar mungkin memiliki sumber daya yang cukup untuk mengurangi biaya produksi informasi dalam annual report kepada pengguna annual report. Othman dan Ameer (2009) berpendapat bahwa berdasarkan political cost theory, maka perusahaan dengan ukuran besar menghadapi biaya politis yang tinggi karena aktivitas perusahaan berdampak terhadap lingkungan dan hal inilah yang mendorong manajemen perusahaan melakukan pengungkapan lingkungan.

\section{$\mathbf{H}_{3}=$ Ukuran perusahaan manufaktur berpengaruh positif terhadap} pengungkapan sosial dan lingkungan perusahaan manufaktur 


\subsection{Pengaruh Manajemen Laba Terhadap Pengungkapan Sosial dan Lingkungan Perusahaan Manufaktur}

Adanya pemisahan kepemilikan dan pengelolaan dalam perusahaan akan menimbulkan asimetri informasi dalam perusahaan dan memungkinkan adanya perilaku oportunistik oleh manajer (agent) yang mungkin memiliki tujuan yang berbeda dengan tujuan pemilik perusahaan (principal) dan mementingkan tujuan pribadi manajer. Perilaku oportunistik manajer ini dapat dicerminkan melalui manajemen laba yang merupakan keputusan pemilihan kebijakan akuntansi yang dilakukan oleh manajer perusahaan dan dipergunakan untuk memaksimalkan kepentingan manajer (Subramanyam dan Wild, 2008). Perumusan hipotesis ini mengasumsikan bahwa manajemen laba yang terjadi bersifat oportunistik.

Prior et al. (2007) berpendapat bahwa manajer yang memiliki motivasi dalam melakukan manajemen laba mungkin akan berusaha untuk mempertahankan posisi jabatannya meskipun manajer tersebut tidak berkompetensi untuk mengelola perusahaan. Salah satu cara manajer untuk mempertahankan jabatannya adalah dengan mengembangkan hubungan dengan stakeholders perusahaan dan aktivis lingkungan. Manajer akan melakukan pengungkapan sosial dan lingkungan perusahaan untuk beberapa tujuan, yaitu meningkatkan legitimasi dari komunitas dan mengurangi pengawasan dari kreditur dan investor. Oktafia (2013) berpendapat bahwa adanya monitoring dan pengawasan dari stakeholders terhadap praktek manajemen laba yang dilakukan manajemen dapat merugikan posisi manajer dan merusak reputasi manajemen. Hal inilah yang memungkinkan manajer memiliki motivasi untuk mengalihkan pengawasan dari stakeholders melalui praktek pengungkapan sosial dan lingkungan perusahaan. Manajemen perusahaan dapat memanipulasi informasi-informasi yang akan disajikan kepada stakeholders penting, misalnya pemerintah, kreditur, atau organisasi sosial dan lingkungan untuk mendapatkan dukungan dan persetujuan atau untuk mengalihkan perhatian dari penolakan stakeholders terhadap kebijakan manajemen (Oktafia, 2013).

Inti dari argumen ini bahwa manajer akan mencoba untuk memuaskan semua kepentingan stakeholders dan mengelola agar perusahaan peduli terhadap isu-isu sosial dan lingkungan sehingga dapat mengalihkan perhatian pemegang saham dari monitoring atas rekayasa laba yang dilakukan manajer (Sun et al., 2010; Prior et al., 2007). Rahmawati dan Dianita (2011) berpendapat bahwa adalah penting bagi manajer untuk memuaskan kepentingan stakeholders, salah satunya adalah dengan pengungkapan sosial dan lingkungan, sehingga membuat citra positif perusahaan di mata stakeholders. Hal inilah yang dapat mengurangi kemungkinan adanya monitoring dari stakeholders terhadap praktek manajemen laba yang dilakukan oleh manajemen.

Gray et al. (1995) berpendapat bahwa corporate social and environmental disclosure (CSED) merupakan sinyal yang dapat mengalihkan perhatian pemegang saham dari monitoring atas rekayasa laba atau isu lain yang mungkin dapat berdampak pada harga saham. Dengan demikian dapat dikatakan bahwa manajemen yang melakukan manajemen laba akan secara aktif melakukan pengungkapan sosial dan lingkungan untuk mengurangi monitoring stakeholders dan sebagai mekanisme pertahanan diri akibat praktek manajemen laba yang dilakukan manajemen.

\section{$\mathbf{H}_{4}=$ Manajemen laba berpengaruh positif terhadap pengungkapan sosial dan lingkungan perusahaan manufaktur}




\subsection{Pengaruh Profitabilitas Perusahaan Manufaktur Terhadap Pengungkapan Sosial dan Lingkungan Perusahaan Manufaktur dengan Mekanisme Corporate Governance Sebagai Variabel Pemoderasi}

Kepemilikan manajerial merupakan salah satu bentuk struktur kepemilikan yang dapat mengatasi masalah agensi yang menyebabkan terciptanya konsep good corporate governance. Ketika laba atau profitabilitas (ROA) perusahaan dijadikan dasar sebagai pemberian bonus kompensasi kepada manajemen, maka sesuai dengan teori agensi, manajemen akan cenderung untuk memaksimalkan laba perusahaan sehingga bonus kompensasi atau utilitas yang didapat akan semakin besar. Dalam konteks mekanisme corporate governance, jika manajer diberikan kesempatan mengelola perusahaan dalam mekanisme kepemilikan manajerial, hal ini akan menurunkan permasalahan agensi karena semakin banyak saham yang dimiliki oleh manajemen maka semakin kuat motivasi manajemen untuk meningkatkan nilai perusahaan. Hal ini sesuai dengan hasil penelitian McConnell dan Servaes (1990) dan Denis et al. (1997) yang menemukan bahwa jika manajer memiliki ekuitas yang signifikan dalam perusahaan, maka manajer akan cenderung untuk membuat keputusan yang meningkatkan nilai pemegang saham. Keputusan untuk meningkatkan nilai pemegang saham ini akan mengurangi konflik kepentingan antara agent dengan principal karena manajemen akan berusaha menyamakan kepentingannya dengan kepentingan perusahaan (pemegang saham dan investor). Jika kegiatan sosial yang dilakukan perusahaan dapat meningkatkan nilai perusahaan, maka hal ini merupakan insentif bagi manajemen dalam melakukan pengungkapan sosial dan lingkungan (Soliman et al., 2012). Nilai perusahaan yang meningkat akibat manajemen perusahaan melakukan pengungkapan sosial dan lingkungan secara langsung juga dapat meningkatkan nilai pemegang saham. Lebih lanjut Jamali et al. (2008) berpendapat bahwa manajemen yang menjalankan corporate governance yang baik merupakan salah satu pilar penting agar perusahaan bersedia melakukan tanggung jawab sosialnya.

\section{$\mathbf{H}_{5}=$ Mekanisme corporate governance akan memperkuat pengaruh profitabilitas perusahaan manufaktur terhadap pengungkapan sosial dan lingkungan perusahaan manufaktur}

\subsection{Pengaruh Struktur Modal Perusahaan Manufaktur Terhadap Pengungkapan Sosial dan Lingkungan Perusahaan Manufaktur dengan Mekanisme Corporate Governance Sebagai Variabel Pemoderasi}

Kepemilikan institusional yang besar juga mendorong manajemen untuk melakukan pengungkapan sosial dan lingkungan perusahaan. Penelitian Beurden dan Gössling (2008) menemukan bahwa lembaga-lembaga institusional akan cenderung untuk berinvestasi pada perusahaan dengan reputasi dan kinerja sosial yang baik. Hal ini mengindikasikan bahwa investor institusional saat ini sangat serius memperhatikan kegiatan sosial dan lingkungan yang dilakukan perusahaan. Huang (2010) berpendapat bahwa investor institusional menginginkan "kriteria standar sosial" tertentu saat memilih perusahaan untuk investasi. Penelitian Aguilera et al. (2007) menemukan bahwa investor institusional cenderung menginginkan perusahaan melakukan kegiatan sosial dan lingkungan dengan dua alasan. Pertama, reputasi perusahaan yang baik dalam kegiatan sosial merupakan sebuah indikator bahwa manajemen yang mengelola perusahaan memiliki kompetensi yang baik. Kedua, motif moral dan menjalin hubungan dengan stakeholders lain di luar perusahaan merupakan sebuah konsekuensi dari lingkungan bisnis saat ini.

Hasil penelitian Aguilera et al. (2007) ini mendukung hasil penelitian Teoh dan Shiu (1990) dan Graves dan Waddock (1994) yang menemukan bahwa investor institusional lebih tertarik berinvestasi pada perusahaan yang aktif melakukan kegiatan sosial dan semakin besar kepemilikan institusional akan berbanding lurus dengan rating CSR perusahaan. Ali dan 
Rizwan (2013) dalam jurnalnya berpendapat bahwa investor institusional mempunyai pengaruh yang besar dalam pengungkapan sosial perusahaan, khususnya untuk perusahaanperusahaan yang beroperasi di negara berkembang. Hasil penelitian Ali dan Rizwan (2013) mendukung hasil penelitian David dan Kochhar (1996) yang memiliki kesimpulan bahwa terdapat hubungan yang positif dan signifikan antara kepemilikan investor institusional pada perusahaan dengan pengungkapan sosial dan lingkungan perusahaan.

$\mathbf{H}_{6}=$ Mekanisme corporate governance akan memperkuat pengaruh struktur modal perusahaan manufaktur terhadap pengungkapan sosial dan lingkungan perusahaan manufaktur

\subsection{Pengaruh Ukuran Perusahaan Manufaktur Terhadap Pengungkapan Sosial dan Lingkungan Perusahaan Manufaktur dengan Mekanisme Corporate Governance Sebagai Variabel Pemoderasi}

Watts dan Zimmerman (1978) berpendapat bahwa perusahaan dengan ukuran besar dalam industri yang operasionalnya memiliki dampak sosial dan lingkungan dapat menghadapi isu legitimasi yang lebih banyak dibandingkan dengan perusahaan dengan ukuran kecil. Ukuran perusahaan yang besar akan mendorong manajemen untuk melakukan pengungkapan sosial dan lingkungan untuk mengurangi pengawasan dan monitoring yang dilakukan stakeholders. Manajemen akan berusaha mengungkapkan aktivitas sosial dan lingkungan perusahaan sebagai "good news" untuk stakeholders. Hal ini didasarkan karena semakin besar ukuran perusahaan, maka jumlah stakeholders yang memonitor perusahaan tersebut akan semakin banyak (Zadeh dan Eskandari, 2012). Watson et al. (2002) menjelaskan bahwa berdasarkan teori legitimasi, pengungkapan sosial dan lingkungan dapat dipergunakan sebagai alat oleh perusahaan dengan ukuran besar untuk mengurangi tekanan regulasi dari pemerintah (political cost hypothesis) dan organisasi lingkungan.

Perusahaan yang berukuran besar dengan kepemilikan manajerial yang tinggi, mungkin akan cenderung untuk melakukan pengungkapan sosial dan lingkungan yang lebih banyak. Hal ini untuk meningkatkan kepercayaan dan meningkatkan keyakinan stakeholders bahwa perusahaan dengan ukuran besar memiliki kepedulian terhadap isu-isu sosial dan lingkungan. Begitu pula dengan mekanisme corporate governance yang lain, misalnya kepemilikan institusional yang tinggi, keberadaan komisaris independen, dan keberadaan komite audit dalam perusahaan dengan ukuran yang besar akan berpengaruh terhadap meningkatnya pengungkapan sosial dan lingkungan yang dilakukan perusahaan.

$\mathrm{H}_{7}=$ Mekanisme corporate governance akan memperkuat pengaruh ukuran perusahaan manufaktur terhadap pengungkapan sosial dan lingkungan perusahaan manufaktur

\subsubsection{Pengaruh Manajemen Laba Terhadap Pengungkapan Sosial dan Lingkungan Perusahaan Manufaktur dengan Mekanisme Corporate Governance Sebagai Variabel Pemoderasi}

Perusahaan dengan struktur kepemilikan manajerial yang lebih banyak mungkin akan memiliki motivasi yang lebih banyak untuk meningkatkan nilai perusahaan. Cara-cara yang dipergunakan untuk meningkatkan nilai perusahaan mungkin saja dengan melakukan manajemen laba maupun tidak melakukan manajemen laba. Jika diasumsikan bahwa manajemen melakukan manajemen laba untuk meningkatkan nilai perusahaan, maka mekanisme corporate governance yang lain dan stakeholders akan mencoba untuk memonitor dan mengawasi praktek manajemen laba yang dilakukan manajemen.

Penelitian sebelumnya yang dilakukan oleh Klein (2002) membuktikan bahwa reliabilitas dan kualitas dari manajemen laba meningkat ketika perilaku oportunistik manajer diawasi dan dimonitor dengan mekanisme corporate governance. Dari sudut pandang teori 
agensi, jumlah dewan direksi yang banyak merupakan mekanisme yang efektif untuk melakukan pengawasan dan monitoring terhadap manajer (Sun et al., 2010). Jumlah yang lebih banyak dari komisioner perusahaan akan menghasilkan proses supervisi yang lebih efektif dalam pengelolaan perusahaan (Collier dan Gregory, 1999). Ebrahim (2007) meneliti mengenai hubungan antara manajemen laba dengan aktivitas monitoring yang dilakukan oleh dewan direksi dan komite audit. Hasil penelitian ini menemukan bahwa terdapat hubungan yang negatif antara manajemen laba dengan aktivitas monitoring dewan direksi dan komite audit dan hubungan ini akan semakin kuat ketika pengawasan komite audit sangat aktif. Untuk mengalihkan pengawasan dan monitoring yang dilakukan terhadap praktek manajemen laba oleh manajemen, maka manajemen akan mencoba untuk meningkatkan hubungan dengan stakeholders lain, misalnya dengan melakukan pengungkapan sosial dan lingkungan.

Penelitian Xie et al. (2003) menemukan hasil bahwa peningkatan dalam jumlah dewan komisaris independen akan cenderung untuk memberikan insentif kepada manajer melakukan kegiatan sosial perusahaan sebagai upaya untuk mengalihkan monitoring dewan komisaris independen. Hasil penelitian Choe dan Lee (2003) menemukan bahwa proporsi yang tinggi dari komisioner independen atau direktur non eksekutif akan membuat dewan lebih independen dari manajemen sehingga proses monitoring yang dilakukan terhadap manajemen perusahaan dapat menjadi lebih baik. Jo dan Harjoto (2011) berpendapat bahwa keberadaan komisioner independen sangat penting dalam monitoring perilaku top manajemen. Pendapat Jo dan Harjoto (2011) ini mendukung pendapat Fama dan Jensen (1983) yang menyatakan bahwa keberadaan komisaris independen merupakan mekanisme yang efektif untuk memonitor perilaku top manajemen. Penelitian Andayani dan Atmini (2012) menemukan hasil bahwa perusahaan yang memiliki dewan komisaris independen memiliki rating yang bagus dalam bidang CSR.

Penjelasan hipotesis 8 ini menunjukkan bahwa ketika monitoring yang dilakukan oleh komisaris independen dan komite audit meningkat terhadap praktek manajemen laba yang dilakukan perusahaan, dengan asumsi bahwa manajemen melakukan manajemen laba, maka manajemen akan mencoba untuk meningkatkan hubungan dengan stakeholders lain melalui pengungkapan sosial dan lingkungan sebagai upaya untuk menghindari monitoring komisaris independen dan komite audit terhadap praktek manajemen laba yang dilakukan oleh manajemen.

\section{$\mathbf{H}_{8}=$ Mekanisme corporate governance akan memperkuat pengaruh manajemen laba terhadap pengungkapan sosial dan lingkungan perusahaan manufaktur}

\section{METODOLOGI PENELITIAN}

\subsection{Populasi Penelitian}

Populasi penelitian ini adalah perusahaan manufaktur yang terdaftar di Bursa Efek Indonesia (BEI). Periode pengamatan penelitian dilakukan untuk tahun 2008-2012. Periode pengamatan penelitian dipilih mulai tahun 2008 karena berdasarkan asumsi bahwa perusahaan telah menerapkan UU No. 40 tahun 2007 dan UU No. 25 tahun 2007. Perusahaan manufaktur yang menjadi populasi dalam penelitian ini dipilih dengan menggunakan beberapa kriteria tertentu yaitu (1) Perusahaan yang telah terdaftar di Bursa Efek Indonesia pada tahun 2008-2012, (2) Perusahaan yang memiliki data mengenai kepemilikan institusional, kepemilikan manajerial, keberadaan komisaris independen, dan keberadaan komite audit dalam perusahaan, (3) Perusahaan yang menerbitkan laporan tahunan (annual report) dan laporan keuangan untuk periode yang berakhir pada tanggal 31 Desember selama tahun 2008-2012. 


\subsection{Jenis dan Sumber Data Penelitian}

Data yang digunakan dalam penelitian ini merupakan data sekunder yang diambil dari laporan keuangan maupun laporan tahunan (annual report) perusahaan sampel dari tahun 2008-2012. Data diperoleh dari Pojok Bursa Fakultas Ekonomi dan Bisnis Universitas Airlangga, Indonesian Capital Market Directory (ICMD), laman resmi Bursa Efek Indonesia, dan laman resmi perusahaan sampel.

\subsection{Definisi Operasional Variabel dan Pengukuran}

4.3.1. Variabel independen

1. Profitabilitas perusahaan

Rasio $R O A$ dipilih karena rasio $R O A$ dapat dipergunakan untuk mengukur dan melihat kemampuan dan efisiensi manajemen dalam menggunakan aset perusahaan untuk menghasilkan laba bersih. operasional perusahaan.

$$
\text { Return on Asset }(R O A)=\frac{\text { Laba bersih akhir tahun } \mathrm{t}}{\text { Total aset tahun } \mathrm{t}}
$$

2. Struktur modal perusahaan

Rasio solvabilitas secara tidak langsung akan menggambarkan kewajiban jangka pendek dan kewajiban jangka panjang perusahaan sehingga dapat diperoleh pemahaman bagaimana struktur modal perusahaan dari pendanaan eksternal.

$$
\text { Debt to Total Assets }(D T A)=\frac{\text { Total liabilitas tahun } \mathrm{t}}{\text { Total aset tahun } \mathrm{t}}
$$

3. Ukuran perusahaan

Ukuran perusahaan pada penelitian ini diukur dengan menggunakan logaritma dari total aset yang dimiliki perusahaan atau ln total aktiva perusahaan.

4. Manajemen laba

Manajemen laba pada penelitian ini diukur menggunakan model Modified Jones. Persamaan model Modified Jones, yaitu

$$
\text { TAC it }=\text { NIit }- \text { CFOit }
$$

Nilai total akrual yang diestimasi dengan persamaan regresi OLS sebagai berikut:

$\mathrm{TAC}_{\mathrm{t}} / \mathrm{A}_{\mathrm{t}-1}=\beta_{1}\left(1 / \mathrm{A}_{\mathrm{it}-1}\right)+\beta_{2}\left(\Delta \mathrm{REV}_{\mathrm{it}}-\Delta \mathrm{REC}_{\mathrm{it}} / \mathrm{A}_{\mathrm{it}-1}\right)+\beta_{3}\left(\mathrm{PPE}_{\mathrm{t}} / \mathrm{A}_{\mathrm{t}-1}\right)+\mathrm{e}$

Dengan menggunakan koefisien regresi pada persamaan $2\left(\beta_{1}, \beta_{2}, \beta_{3}\right)$, nilai non discretionary accrual (NDA) dapat dihitung dengan rumus:

$\mathrm{NDA}_{i t}=\beta_{1}\left(1 / \mathrm{A}_{\mathrm{it}-1}\right)+\beta_{2}\left(\Delta \mathrm{REV}_{\mathrm{it}}-\Delta \mathrm{REC}_{\mathrm{it}} / \mathrm{A}_{\mathrm{it}-1}\right)+\beta_{3}\left(\mathrm{PPE}_{\mathrm{it}} / \mathrm{A}_{\mathrm{it}-1}\right)$

Selanjutnya, nilai discretionary accrual (DA) dapat dihitung sebagai berikut:

$$
\mathrm{DA}_{\mathrm{it}}=\mathrm{TAC}_{\mathrm{it}}-\mathrm{NDA}_{\mathrm{it}}
$$

Keterangan :

TAC $\mathrm{t}=$ Total akrual perusahaan i pada periode ke $\mathrm{t}$

Nlit $=$ Laba bersih perusahaan $\mathrm{i}$ pada periode ke $\mathrm{t}$

CFOit = Arus kas dari aktivitas operasi perusahaan i pada periode ke $\mathrm{t}$

$\mathrm{DA}_{\mathrm{it}} \quad=$ Discretionary accrual perusahaan i pada periode ke $\mathrm{t}$ 


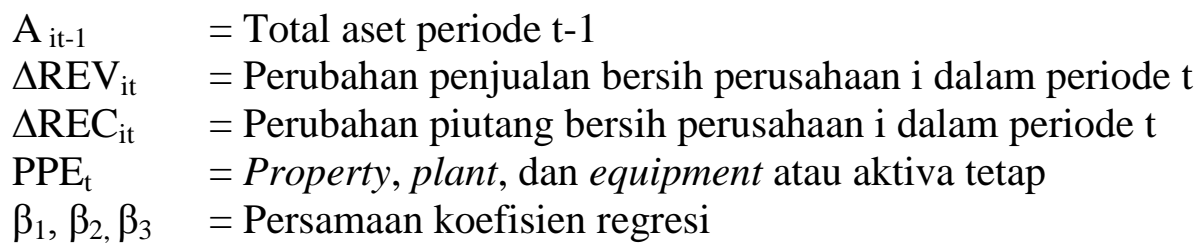

\subsubsection{Variabel dependen}

Jumlah item-item indikator pengungkapan sosial dan lingkungan yang harus diungkapkan berjumlah 96 item yang merupakan total item pengungkapan yang terdapat pada jurnal Sutantoputra (2009) dan Clarkson et al. (2007) dengan skor maksimal pengungkapan adalah 178.

\subsubsection{Variabel moderasi}

1. Kepemilikan manajerial Kepemilikan manajerial diukur dengan persentase dari kepemilikan saham yang dimiliki oleh dewan direksi dan dewan komisaris perusahaan dibagi dengan total jumlah saham perusahaan yang beredar.

2. Kepemilikan institusional

Kepemilikan institusional diukur dengan persentase dari nilai jumlah saham perusahaan yang dimiliki institusi dibagi dengan total jumlah saham perusahaan yang beredar.

3. Keberadaan komisaris independen

Keberadaan komisaris independen diukur dengan menggunakan variabel dummy, yaitu diberikan nilai 1 jika perusahaan memiliki komisaris independen dan nilai 0 jika perusahaan tidak memiliki komisaris independen.

4. Keberadaan komite audit

Pada penelitian ini keberadaan komite audit diukur menggunakan variabel dummy, yaitu diberikan nilai 1 jika perusahaan memiliki komite audit dan nilai 0 jika perusahaan tidak memiliki komite audit.

\subsection{Analisis Faktor}

Analisis faktor dipergunakan untuk menguji pengaruh variabel kepemilikan manajerial, variabel kepemilikan institusional, variabel keberadaan komisaris independen, dan variabel keberadaan komite audit sebagai indikator dari mekanisme corporate governance.

Sebelum mencari nilai faktor skor, hal yang terlebih dahulu harus dilakukan adalah memastikan bahwa indikator layak dimasukan dalam analisis faktor. Syarat kecukupan yang pertama adalah dari KMO measure of sampling adequacy (MSA) dan Barlett's test (Ghozali, 2011). Jika KMO MSA $\geq 0,5$ maka memenuhi syarat kecukupan analisis faktor. Selain itu, Barlett's test menunjukan signifikansi kurang dari 0,05.

Selanjutnya menentukan indikator mana yang layak untuk dianalisis faktor. Prosedurnya adalah jika nilai MSA $\geq 0,5$ maka indikator tersebut layak untuk digunakan untuk analisis faktor dan sebaliknya (Ghozali, 2011). Jika hasil dari skor loading factor kurang dari 0,4 maka indikator tersebut tidak boleh dimasukan dalam analisis faktor karena indikator tersebut tidak memberikan kontribusi dalam pembentukan mekanisme corporate governance.

\subsection{Teknik atau Metode Analisis Data}

Teknik atau metode analisis data yang dipergunakan dalam penelitian ini adalah analisis regresi moderasi atau moderated regression analysis (MRA). Model analisis regresi 
moderasi yang dikembangkan dalam penelitian ini sesuai dengan model yang terdapat dalam jurnal Sharma et al. (1981) dan Liana (2009).

Model persamaan analisis regresi moderasi untuk menguji hipotesis $\mathrm{H}_{5}$ sampai $\mathrm{H}_{8}$ pada penelitian ini adalah:

Model 1 (Persamaan untuk variabel independen profitabilitas perusahaan)

$\operatorname{CSED}=\alpha+\beta_{1} \mathrm{ROA}+\mathrm{e}$.

CSED $=\alpha+\beta_{1} \mathrm{ROA}+\beta_{2} \mathrm{CG}+\mathrm{e}$

$\mathrm{CSED}=\alpha+\beta_{1} \mathrm{ROA}+\beta_{2} \mathrm{CG}+\beta_{3} \mathrm{ROA} * \mathrm{CG}+\mathrm{e}$

Model 2 (Persamaan untuk variabel independen struktur modal perusahaan)

CSED $=\alpha+\beta_{1}$ LEV + e.

$\mathrm{CSED}=\alpha+\beta_{1} \mathrm{LEV}+\beta_{2} \mathrm{CG}+\mathrm{e}$

$\mathrm{CSED}=\alpha+\beta_{1} \mathrm{LEV}+\beta_{2} \mathrm{CG}+\beta_{3} \mathrm{LEV} * \mathrm{CG}+\mathrm{e}$.

Model 3 (Persamaan untuk variabel independen ukuran perusahaan)

CSED $=\alpha+\beta_{1}$ SIZE + e.

CSED $=\alpha+\beta_{1}$ SIZE $+\beta_{2}$ CG $+\mathrm{e}$

CSED $=\alpha+\beta_{1}$ SIZE $+\beta_{2}$ CG $+\beta_{3}$ SIZE $* G+\mathrm{e}$

Model 4 (Persamaan untuk variabel independen manajemen laba)

CSED $=\alpha+\beta_{1}$ DACC $+\mathrm{e}$

CSED $=\alpha+\beta_{1}$ DACC $+\beta_{2} \mathrm{CG}+\mathrm{e}$.

$\mathrm{CSED}=\alpha+\beta_{1} \mathrm{DACC}+\beta_{2} \mathrm{CG}+\beta_{3} \mathrm{DACC} * \mathrm{CG}+\mathrm{e}$.

Keterangan:

CSED = Pengungkapan sosial dan lingkungan perusahaan

ROA = Profitabilitas perusahaan

LEV = Struktur modal perusahaan

SIZE = Ukuran perusahaan

DACC = Manajemen laba

CG = Mekanisme corporate governance

$\alpha \quad=$ Intercept model regresi

$\beta \quad=$ Koefisien model regresi

e $\quad=$ Nilai error

Variabel moderasi dapat dikelompokkan menjadi 4 jenis variabel moderasi (Ghozali, 2011), yaitu

1. Variabel moderasi murni (pure moderator)

Variabel moderasi murni adalah jenis variabel moderasi yang dapat diidentifikasi melalui koefisien $\beta_{2}$ dan $\beta_{3}$ dalam persamaan (3) yaitu jika koefisien $\beta_{2}$ dinyatakan tidak signifikan tetapi koefisien $\beta_{3}$ signifikan secara statistika.

2. Variabel moderasi semu (quasi moderator)

Variabel moderasi semu adalah jenis variabel moderasi yang dapat diidentifikasi melalui koefisien $\beta_{2}$ dan $\beta_{3}$ dalam persamaan (3) yaitu jika koefisien $\beta_{2}$ dinyatakan signifikan dan koefisien $\beta_{3}$ signifikan secara statistika.

3. Variabel moderasi potensial (homologizer moderator)

Variabel moderasi potensial adalah jenis variabel moderasi yang dapat diidentifikasi melalui koefisien $\beta_{2}$ dan $\beta_{3}$ dalam persamaan (3) yaitu jika koefisien $\beta_{2}$ dinyatakan tidak signifikan dan koefisien $\beta_{3}$ tidak signifikan secara statistika. 
4. Variabel moderasi sebagai predictor (predictor moderator)

Variabel moderasi sebagai predictor adalah jenis variabel moderasi yang dapat diidentifikasi melalui koefisien $\beta_{2}$ dan $\beta_{3}$ dalam persamaan (3) yaitu jika koefisien $\beta_{2}$ dinyatakan signifikan dan koefisien $\beta_{3}$ tidak signifikan secara statistika.

\subsection{Pengujian Hipotesis}

Pengujian hipotesis dalam penelitian ini akan menggunakan uji t dan koefisien determinasi $\left(\mathrm{R}^{2}\right)$.

a. Uji t (t-test)

Uji t dipergunakan untuk menguji hipotesis $\mathrm{H}_{1}$ sampai $\mathrm{H}_{4}$. Taraf signifikansi yang digunakan dalam analisis ini sebesar 0,05.

b. Koefisien Determinasi $\left(\mathrm{R}^{2}\right)$

Nilai koefisien determinasi terletak antara 0 dan $1\left(0<\mathrm{R}^{2}<1\right)$, di mana semakin tinggi nilai $\mathrm{R}^{2}$ suatu regresi atau semakin mendekati 1 maka hasil regresi tersebut semakin baik.

\subsection{Uji Asumsi Klasik}

a. Uji Normalitas

Uji t mengasumsikan bahwa nilai residual mengikuti distribusi normal. Kalau asumsi ini dilanggar maka uji statistik menjadi tidak valid untuk jumlah sampel yang kecil (Ghozali, 2011).

b. Uji Multikolinieritas

Uji multikolinieritas bertujuan untuk menguji apakah dalam model regresi ditemukan adanya korelasi antar variabel bebas (Ghozali, 2011). Model yang baik seharusnya tidak terjadi korelasi diantara variabel bebas.

\section{c. Uji Heteroskedastisitas}

Menurut Ghozali (2011), uji heteroskedastisitas bertujuan menguji apakah dalam model regresi terjadi ketidaksamaan variance dari residual satu pengamatan ke pengamatan yang lain. Model regresi yang baik adalah yang homoskedastisitas atau tidak terjadi heteroskedastisitas.

\section{d. Uji Autokorelasi}

Uji autokorelasi dilakukan untuk mengetahui apakah model regresi terjadi gejala autokorelasi atau tidak. Gejala autokorelasi adalah adanya korelasi pada varians error antar periode. Gejala ini menyebabkan terjadinya interkorelasi diantara observasi yang berurutan sehingga hasil regresi menjadi tidak efisien karena varians tidak minimum dan menjadikan tes signifikansi tidak akurat (Ghozali, 2011).

\section{ANALISIS DAN PEMBAHASAN HASIL PENELITIAN \\ 5.1. Gambaran Umum Populasi Penelitian}

Populasi total dalam penelitian ini berjumlah 135 perusahaan. Berdasarkan kriteria yang ada, maka penelitian ini menggunakan 74 perusahaan sebagai populasi penelitian dengan total observasi penelitian selama lima tahun sebanyak 370 observasi. Data populasi yang dipergunakan dalam penelitian ini termasuk data sensus karena dari total 74 perusahaan semuanya dipergunakan sebagai sampel penelitian. 
Tabel 5.1

Populasi penelitian

\begin{tabular}{|l|c|}
\hline Jumlah populasi penelitian: & 135 \\
\hline $\begin{array}{l}\text { Kriteria pengambilan sampel: } \\
\text { 1. Tidak mempublikasikan atau tidak terdapat data } \\
\text { laporan keuangan serta annual report secara lengkap } \\
\text { selama periode 2008-2012 selama dua tahun berturut- } \\
\text { turut atau lebih }\end{array}$ & \\
$\begin{array}{l}\text { 2. Tidak mempublikasikan laporan tahunan dengan } \\
\text { satuan nilai rupiah dan tidak menggunakan tahun buku } \\
\text { desember }\end{array}$ & (13) \\
\hline Jumlah populasi yang dipergunakan & $\mathbf{7 4}$ \\
\hline Jumlah observasi penelitian selama 5 tahun & $\mathbf{3 7 0}$ \\
\hline
\end{tabular}

Sumber: Data olahan peneliti, 2014.

\subsection{Interpretasi Hasil Penelitian}

\subsubsection{Hasil Analisis Faktor}

Pada tabel 5.2 dapat dilihat bahwa seluruh indikator mempunyai KMO MSA $\geq 0,5$ yaitu sebesar 0,502. Barlett's test menunjukan signifikansi kurang dari 0,05 yaitu 0,000. Untuk itu keempat mekanisme corporate governance tersebut telah tepat untuk menjadi variabel komposit.

Tabel 5.2

Hasil analisis faktor

\begin{tabular}{|c|c|c|c|c|}
\hline Komposit & Indikator & $\begin{array}{c}\text { Barlett's } \\
\text { test }\end{array}$ & $\begin{array}{l}\text { KMO } \\
\text { MSA }\end{array}$ & $\begin{array}{c}\text { Loading } \\
\text { Factor }\end{array}$ \\
\hline \multirow{4}{*}{$\begin{array}{c}\text { Mekanisme } \\
\text { corporate } \\
\text { governance }\end{array}$} & $\begin{array}{c}\text { Kepemilikan } \\
\text { manajerial }\end{array}$ & \multirow{4}{*}{$\begin{array}{c}124,027 \\
(\mathrm{sig}= \\
0,000)\end{array}$} & 0,502 & 0,637 \\
\hline & $\begin{array}{c}\text { Kepemilikan } \\
\text { institusional }\end{array}$ & & 0,502 & 0,622 \\
\hline & $\begin{array}{c}\text { Keberadaan } \\
\text { komisaris } \\
\text { independen }\end{array}$ & & 0,502 & 0,479 \\
\hline & $\begin{array}{c}\text { Keberadaan } \\
\text { komite audit }\end{array}$ & & 0,502 & 0,655 \\
\hline
\end{tabular}

Sumber: Hasil olahan SPSS, 2014.

\subsubsection{Hasil Uji Asumsi Klasik}

\section{Uji Normalitas}

Dari tabel uji asumsi klasik dapat dilihat bahwa tingkat signifikansi one sample Smirnov-Kolmogorov menunjukkan angka yang lebih besar dari 0,05 sehingga dapat disimpulkan bahwa data terdistribusi normal. Berdasarkan teori central limit (central limit theory), semakin besar jumlah sampel maka distribusinya cenderung ke distribusi normal. Jika jumlah sampel yang diambil besar, yaitu $\mathrm{n} \geq 30$, maka distribusi dianggap normal (Trihendradi, 2007). Penelitian ini menggunakan 370 sampel atau observasi, dengan demikian model regresi 3.1, 3.2, dan 3.3 telah dianggap memenuhi uji normalitas. Hal ini didukung dengan tabel berikut. 
Tabel 5.3

Hasil uji normalitas

\begin{tabular}{|l|c|c|}
\hline \multicolumn{1}{|c|}{ Model Regresi } & Nilai Asymp. Sig & Kesimpulan \\
\hline Regresi 1.1 & 0,212 & Normal \\
\hline Regresi 1.2 & 0,203 & Normal \\
\hline Regresi 1.3 & 0,204 & Normal \\
\hline Regresi 2.1 & 0,281 & Normal \\
\hline Regresi 2.2 & 0,251 & Normal \\
\hline Regresi 2.3 & 0,253 & Normal \\
\hline Regresi 3.1 & 0,049 & Tidak Normal \\
\hline Regresi 3.2 & 0,025 & Tidak Normal \\
\hline Regresi 3.3 & 0,013 & Tidak Normal \\
\hline Regresi 4.1 & 0,099 & Normal \\
\hline Regresi 4.2 & 0,182 & Normal \\
\hline Regresi 4.3 & 0,161 & Normal \\
\hline
\end{tabular}

Sumber: Hasil olahan SPSS, 2014.

\section{Uji Multikolonieritas}

Variabel pada model regresi 3.3 mengalami multikolonieritas. Multikolonieritas yang terjadi pada model regresi 3.3 dapat diabaikan karena model regresi 3.1, 3.2, dan 3.3 dianggap telah memenuhi asumsi normalitas. Disimpulkan bahwa model regresi dalam penelitian ini tidak ada multikolinieritas antar variabel independen dalam model regresi karena nilai VIF $<10$ dan nilai tolerance $>0,1$.

Tabel 5.4

Hasil uji multikolonieritas

\begin{tabular}{|c|c|c|c|c|}
\hline $\begin{array}{c}\text { Model } \\
\text { Regresi }\end{array}$ & Variabel & Nilai VIF & $\begin{array}{c}\text { Nilai } \\
\text { Tolerance }\end{array}$ & Kesimpulan \\
\hline Regresi 1.1 & ROA & 1,000 & 1,000 & Bebas Multikolonieritas \\
\hline Regresi 1.2 & ROA & 1,005 & 0,995 & Bebas Multikolonieritas \\
& CG & 1,005 & 0,995 & Bebas Multikolonieritas \\
\hline Regresi 1.3 & ROA & 1,170 & 0,855 & Bebas Multikolonieritas \\
& CG & 1,340 & 0,746 & Bebas Multikolonieritas \\
& ROA*CG & 1,534 & 0,652 & Bebas Multikolonieritas \\
\hline Regresi 2.1 & LEV & 1,000 & 1,000 & Bebas Multikolonieritas \\
\hline Regresi 2.2 & LEV & 1,009 & 0,991 & Bebas Multikolonieritas \\
& CG & 1,009 & 0,991 & Bebas Multikolonieritas \\
\hline Regresi 2.3 & LEV & 1,026 & 0,975 & Bebas Multikolonieritas \\
& CG & 7,727 & 0,129 & Bebas Multikolonieritas \\
& LEV*CG & 7,797 & 0,128 & Bebas Multikolonieritas \\
\hline Regresi 3.1 & SIZE & 1,000 & 1,000 & Bebas Multikolonieritas \\
\hline Regresi 3.2 & SIZE & 1,025 & 0,975 & Bebas Multikolonieritas \\
& CG & 1,025 & 0,975 & Bebas Multikolonieritas \\
\hline Regresi 3.3 & SIZE & 1,026 & 0,975 & Bebas Multikolonieritas \\
& CG & 347,452 & 0,003 & Terjadi Multikolonieritas \\
& SIZE*CG & 347,284 & 0,003 & Terjadi Multikolonieritas \\
\hline Regresi 4.1 & DACC & 1,000 & 1,000 & Bebas Multikolonieritas \\
\hline Regresi 4.2 & DACC & 1,001 & 0,999 & Bebas Multikolonieritas \\
& CG & 1,001 & 0,999 & Bebas Multikolonieritas \\
\hline Regresi 4.3 & DACC & 1,253 & 0,798 & Bebas Multikolonieritas \\
\hline
\end{tabular}




\begin{tabular}{|c|c|c|c|c|}
\hline & CG & 1,025 & 0,976 & Bebas Multikolonieritas \\
& DACC*CG & 1,273 & 0,785 & Bebas Multikolonieritas \\
\hline
\end{tabular}

Sumber: Hasil olahan SPSS, 2014

\section{Uji Heteroskedastisitas}

Dari grafik heteroskedastisitas yang dihasilkan dari SPSS, terlihat bahwa grafik plot antara nilai prediksi variabel dependen, yaitu ZPRED dengan nilai residualnya, yaitu SRESID tidak terdapat pola tertentu dan pola titik-titik menyebar pada grafik scatterplot sehingga dapat disimpulkan tidak terjadi heterokedastisitas (lampiran hasil uji heteroskedastisitas).

\section{Uji Autokorelasi}

Nilai Durbin Watson pada tabel di bawah ini mayoritas terbebas dari autokorelasi, namun untuk model regresi 3.2 dan model regresi 3.3 mengalami autokorelasi tetapi hal ini tidak menjadi fokus penelitian karena data telah terdistribusi normal.

Tabel 5.5

Hasil uji autokorelasi

\begin{tabular}{|l|c|c|c|c|}
\hline Model Regresi & Nilai Du & Nilai Durbin Watson & Nilai 4-Du & Kesimpulan \\
\hline Regresi 1.1 & 1.7785 & 2,023 & 2.2215 & Bebas Autokorelasi \\
\hline Regresi 1.2 & 1.7887 & 2,069 & 2.2113 & Bebas Autokorelasi \\
\hline Regresi 1.3 & 1.7990 & 2,078 & 2.2010 & Bebas Autokorelasi \\
\hline Regresi 2.1 & 1.7785 & 2,001 & 2.2215 & Bebas Autokorelasi \\
\hline Regresi 2.2 & 1.7887 & 2,064 & 2.2113 & Bebas Autokorelasi \\
\hline Regresi 2.3 & 1.7990 & 2,063 & 2.2010 & Bebas Autokorelasi \\
\hline Regresi 3.1 & 1.7785 & 2,205 & 2.2215 & Bebas Autokorelasi \\
\hline Regresi 3.2 & 1.7887 & 2,213 & 2.2113 & Tidak Bebas Autokorelasi \\
\hline Regresi 3.3 & 1.7990 & 2,207 & 2.2010 & Tidak Bebas Autokorelasi \\
\hline Regresi 4.1 & 1.7785 & 2,007 & 2.2215 & Bebas Autokorelasi \\
\hline Regresi 4.2 & 1.7887 & 2,054 & 2.2113 & Bebas Autokorelasi \\
\hline Regresi 4.3 & 1.7990 & 2,051 & 2.2010 & Bebas Autokorelasi \\
\hline
\end{tabular}

Sumber: Hasil olahan SPSS, 2014.

\subsection{Hasil Analisis Regresi Moderasi}

Tabel 5.6

Analisis regresi moderasi untuk model 1

\begin{tabular}{|l|c|c|c|c|c|c|}
\hline \multirow{2}{*}{ Variabel Penelitian } & \multicolumn{2}{|c|}{ Model Regresi 1.1 } & \multicolumn{2}{c|}{ Model Regresi 1.2 } & \multicolumn{2}{c|}{ Model Regresi 1.3 } \\
\cline { 2 - 7 } & Koefisien & Signifikansi & Koefisien & Signifikansi & Koefisien & Signifikansi \\
\hline Konstanta & 0,273 & 0,000 & 0,273 & 0,000 & 0,272 & 0,000 \\
\hline ROA & 0,270 & 0,000 & 0,263 & 0,000 & 0,282 & 0,000 \\
\hline CG & - & - & 0,013 & 0,119 & 0,017 & 0,079 \\
\hline ROA*CG & - & - & - & - & $-0,061$ & 0,418 \\
\hline R & 0,237 & - & 0,250 & - & 0,253 & - \\
\hline R square & 0,056 & - & 0,063 & - & 0,064 & - \\
\hline Sig F & 0,000 & - & 0,000 & - & 0,000 & - \\
\hline
\end{tabular}

Sumber: Hasil olahan SPSS, 2014. 
a. Untuk model regresi 1.1, ROA memiliki tingkat signifikansi yang lebih kecil dari 0,05 yaitu 0,000 dengan nilai koefisien 0,270 yang berarti ROA berpengaruh positif terhadap pengungkapan informasi sosial dan lingkungan (CSED).

b. Untuk model regresi 1.3, ROA memiliki tingkat signifikansi yang lebih kecil dari 0,05 yaitu 0,000 yang berarti berpengaruh terhadap pengungkapan informasi sosial dan lingkungan (CSED), sedangkan untuk variabel interaksi ROA dan corporate governance (CG) tidak memoderasi pengungkapan informasi sosial dan lingkungan (CSED). Pada model ini, variabel CG termasuk homologizer moderator (koefisien $\beta_{2}$ dan $\beta_{3}$ tidak signifikan).

Tabel 5.7

Analisis regresi moderasi untuk model 2

\begin{tabular}{|l|c|c|c|c|c|c|}
\hline \multirow{2}{*}{ Variabel Penelitian } & \multicolumn{2}{|c|}{ Model Regresi 2.1 } & \multicolumn{2}{c|}{ Model Regresi 2.2 } & \multicolumn{2}{c|}{ Model Regresi 2.3 } \\
\cline { 2 - 7 } & Koefisien & Signifikansi & Koefisien & Signifikansi & Koefisien & Signifikansi \\
\hline Konstanta & 0,351 & 0,000 & 0,354 & 0,000 & 0,354 & 0,000 \\
\hline LEV & -0.114 & 0,000 & $-0,120$ & 0,000 & $-0,118$ & 0,000 \\
\hline CG & - & - & 0,019 & 0,021 & 0,032 & 0,162 \\
\hline LEV*CG & - & - & - & - & $-0,030$ & 0,542 \\
\hline R & 0,214 & - & 0,244 & - & 0,246 & - \\
\hline R square & 0,046 & - & 0,059 & - & 0,060 & - \\
\hline Sig F & 0,000 & - & 0,000 & - & 0,000 & - \\
\hline
\end{tabular}

Sumber: Hasil olahan SPSS, 2014.

a. Untuk model regresi 2.1, leverage (LEV) memiliki tingkat signifikansi yang lebih kecil dari 0,05 yaitu 0,000 dengan nilai koefisien -0,114 yang berarti LEV berpengaruh negatif terhadap pengungkapan informasi sosial dan lingkungan (CSED).

b. Untuk model regresi 2.3, leverage (LEV) memiliki tingkat signifikansi yang lebih kecil dari 0,05 yaitu 0,000 yang berarti berpengaruh terhadap pengungkapan informasi sosial dan lingkungan (CSED), sedangkan untuk variabel interaksi leverage (LEV) dan corporate governance (CG) tidak memoderasi pengungkapan informasi sosial dan lingkungan (CSED). Pada model ini, variabel CG termasuk homologizer moderator (koefisien $\beta_{2}$ dan $\beta_{3}$ tidak signifikan).

Tabel 5.8

Analisis regresi moderasi untuk model 3

\begin{tabular}{|l|c|c|c|c|c|c|}
\hline \multirow{2}{*}{ Variabel Penelitian } & \multicolumn{2}{|c|}{ Model Regresi 3.1 } & \multicolumn{2}{c|}{ Model Regresi 3.2 } & \multicolumn{2}{c|}{ Model Regresi 3.3 } \\
\cline { 2 - 7 } & Koefisien & Signifikansi & Koefisien & Signifikansi & Koefisien & Signifikansi \\
\hline Konstanta & $-1,031$ & 0,000 & $-1,021$ & 0,000 & $-1,029$ & 0,000 \\
\hline SIZE & 0,048 & 0,000 & 0,047 & 0,000 & 0,048 & 0,000 \\
\hline CG & - & - & 0,004 & 0,635 & $-0,254$ & 0,069 \\
\hline SIZE*CG & - & - & - & - & 0,010 & 0,065 \\
\hline R & 0,472 & - & 0,472 & - & 0,480 & - \\
\hline R square & 0,223 & - & 0,223 & - & 0,230 & - \\
\hline Sig F & 0,000 & - & 0,000 & - & 0,000 & - \\
\hline
\end{tabular}

Sumber: Hasil olahan SPSS, 2014. 
a. Untuk model regresi 3.1, SIZE memiliki tingkat signifikansi yang lebih kecil dari 0,05 yaitu 0,000 dengan nilai koefisien 0,048 yang berarti SIZE berpengaruh positif terhadap pengungkapan informasi sosial dan lingkungan (CSED).

b. Untuk model regresi 3.3, SIZE memiliki tingkat signifikansi yang lebih kecil dari 0,05 yaitu 0,000 yang berarti berpengaruh terhadap pengungkapan informasi sosial dan lingkungan (CSED), sedangkan untuk variabel interaksi SIZE dan corporate governance (CG) tidak memoderasi pengungkapan informasi sosial dan lingkungan (CSED). Pada model ini, variabel CG termasuk homologizer moderator (koefisien $\beta_{2}$ dan $\beta_{3}$ tidak signifikan).

Tabel 5.9

Analisis regresi moderasi untuk model 4

\begin{tabular}{|l|c|c|c|c|c|c|}
\hline \multirow{2}{*}{ Variabel Penelitian } & \multicolumn{2}{|c|}{ Model Regresi 4.1 } & \multicolumn{2}{c|}{ Model Regresi 4.2 } & \multicolumn{2}{c|}{ Model Regresi 4.3 } \\
\cline { 2 - 7 } & Koefisien & Signifikansi & Koefisien & Signifikansi & Koefisien & Signifikansi \\
\hline Konstanta & 0,295 & 0,000 & 0,295 & 0,000 & 0,294 & 0,000 \\
\hline DACC & $-0,081$ & 0,162 & $-0,079$ & 0,173 & $-0,070$ & 0,282 \\
\hline CG & - & - & 0,015 & 0,070 & 0,016 & 0,066 \\
\hline DACC*CG & - & - & - & - & $-0,024$ & 0,757 \\
\hline R & 0,073 & - & 0,119 & - & 0,120 & - \\
\hline R square & 0,005 & - & 0,014 & - & 0,014 & - \\
\hline Sig F & 0,162 & - & 0,072 & - & 0,149 & - \\
\hline
\end{tabular}

Sumber: Hasil olahan SPSS, 2014.

a. Untuk model regresi 4.1, DACC memiliki tingkat signifikansi yang lebih besar dari 0,05 yaitu 0,162 yang berarti tidak berpengaruh terhadap pengungkapan informasi sosial dan lingkungan (CSED).

b. Untuk model regresi 4.3, DACC dan corporate governance memiliki tingkat signifikansi yang lebih besar dari 0,05 yaitu 0,282 dan 0,066 yang berarti tidak berpengaruh terhadap pengungkapan informasi sosial dan lingkungan (CSED), sedangkan untuk variabel interaksi DACC dan corporate governance tidak memoderasi pengungkapan informasi sosial dan lingkungan (CSED). Pada model ini, variabel CG termasuk homologizer moderator (koefisien $\beta_{2}$ dan $\beta_{3}$ tidak signifikan).

\subsection{Pembahasan}

5.4.1. Pengaruh Profitabilitas Perusahaan Manufaktur Terhadap Pengungkapan Sosial dan Lingkungan Perusahaan Manufaktur

Hasil penelitian ini konsisten dengan hasil penelitian Setyorini dan Ishak (2012), Lucyanda dan Siagian (2012), dan Mulyadi dan Anwar (2012). Hasil pengujian yang menerima hipotesis 1 ini sesuai dengan pendapat Lucyanda dan Siagian (2012), Mulyadi dan Anwar (2012), dan Liu et al. (2009) yang menjelaskan bahwa perusahaan yang memiliki kinerja keuangan yang tinggi, dalam hal ini laba atau profit yang tinggi, akan cenderung untuk melakukan pengungkapan aktivitas sosial dan lingkungan yang lebih banyak daripada perusahaan dengan kinerja keuangan yang rendah. Hal ini akan berpengaruh terhadap nilai perusahaan dan keputusan berinvestasi oleh investor. Liu et al. (2009) berdasarkan hasil penelitiannya mengatakan bahwa investor akan mencoba untuk berinvestasi pada perusahaan yang memiliki pengungkapan sosial dan lingkungan yang lebih banyak karena investor memiliki kepercayaan yang sangat tinggi terhadap reputasi manajemen perusahaan yang dibuktikan dengan adanya kepedulian perusahaan terhadap isu-isu sosial dan lingkungan. 
Pendapat lain yang dapat menjelaskan kenapa perusahaan dengan profitabilitas yang tinggi cenderung untuk melakukan pengungkapan sosial dan lingkungan yang lebih banyak dikemukakan dalam hasil penelitian Mia dan Mamun (2011). Mia dan Mamun (2011) berpendapat bahwa perusahaan yang memiliki profitabilitas yang tinggi akan cenderung menjadi perhatian semua stakeholders perusahaan dan semua dampak dari aktivitas operasional perusahaan menjadi perhatian masyarakat. Profitabilitas perusahaan yang tinggi dapat dijadikan salah satu alasan kelompok stakeholders untuk menekan perusahaan agar mau peduli terhadap kondisi sosial dan lingkungan di sekitar perusahaan. Argumentasi ini memberikan penjelasan bahwa manajemen perusahaan mau tidak mau akan melakukan pengungkapan sosial dan lingkungan sebagai bentuk tanggapan terhadap perhatian stakeholders. Manajemen perusahaan akan mencoba untuk mencari legitimasi terhadap keberadaan perusahaan dengan menunjukkan kepedulian manajemen perusahaan terhadap isu-isu sosial dan lingkungan. Chariri (2008) berpendapat bahwa jika perusahaan tidak melaksanakan kegiatan sosial dan lingkungan yang seharusnya menjadi kewajiban perusahaan maka akan terjadi legitimacy gap, yaitu perbedaan antara nilai perusahaan akibat kinerja keuangan yang dihasilkan perusahaan dengan nilai sosial perusahaan yang berkembang di masyarakat.

\subsubsection{Pengaruh Struktur Modal Perusahaan Manufaktur Terhadap Pengungkapan Sosial dan Lingkungan Perusahaan Manufaktur}

Hasil penelitian ini tidak mendukung hasil penelitian Setyorini dan Ishak (2012), dan Lucyanda dan Siagian (2012) yang menemukan bahwa leverage perusahaan tidak memiliki pengaruh sama sekali terhadap pengungkapan sosial dan lingkungan perusahaan. Hasil penelitian ini juga tidak sejalan dengan hasil penelitian Kamil dan Herusetya (2012), Alarussi et al. (2009), Ma dan Zhao (2009), dan Christopher dan Filipovic (2008) yang menyatakan bahwa perusahaan dengan leverage yang tinggi akan cenderung untuk melakukan pengungkapan sosial dan lingkungan. Satu argumentasi yang dapat menjelaskan hasil penelitian ini adalah bahwa informasi mengenai aktivitas sosial dan lingkungan perusahaan belum menjadi suatu kebutuhan informasi yang penting bagi kreditur perusahaan manufaktur di Indonesia. Meskipun hasil penelitian ini menunjukkan bahwa jika rasio solvabilitas suatu perusahaan rendah maka pengungkapan sosial dan lingkungan perusahaan tersebut meningkat, hal ini belum mencerminkan bahwa permintaan informasi aktivitas sosial dan lingkungan tersebut benar-benar berasal dari kreditur perusahaan. Hasil penelitian ini sangat berbeda dengan hasil penelitian Alarussi et al. (2009) di Malaysia yang menjelaskan bahwa perusahaan yang mengalami monitoring atau pengawasan yang ketat dari kreditur akibat rasio hutang/modal yang tinggi akan cenderung untuk meningkatkan tingkat pengungkapan sosial perusahaan sebagai upaya untuk mengatasi permasalahan monitoring atau pengawasan yang ketat ini.

Argumentasi lain yang dapat mendukung hasil penelitian ini adalah bahwa perusahaan dengan tingkat leverage yang tinggi akan cenderung untuk memiliki kemungkinan melakukan pelanggaran kontrak hutang dengan kreditur. Perusahaan dalam hal ini gagal untuk menjaga rasio-rasio keuangan sebagai bagian dari perjanjian dengan kreditur. Untuk mengatasi hal ini maka manajemen akan melaporkan laba periode sekarang lebih tinggi daripada laba di masa depan sebagai “good news” bagi kreditur. Hal ini akan berimplikasi bahwa perusahaan akan mengurangi biaya-biaya agar laba yang dilaporkan semakin tinggi. Biaya-biaya ini kemungkinan besar adalah biaya-biaya untuk melakukan aktivitas sosial dan lingkungan perusahaan dan pengungkapan aktivitas tersebut (Wijaya, 2012). Nur dan Priantinah (2012) berpendapat bahwa berdasarkan teori agensi, manajemen perusahaan dengan tingkat leverage yang tinggi akan mengurangi pengungkapan mengenai aktivitas sosial dan lingkungan perusahaan agar tidak menjadi sorotan dari debtholders. Setyorini dan 
Ishak (2012) berpendapat bahwa rasio solvabilitas yang tinggi akan menurunkan kemampuan dan sumber daya perusahaan untuk bisa melakukan aktivitas sosial dan lingkungan. Keputusan untuk melakukan aktivitas sosial dan lingkungan dapat menurunkan laba perusahaan. Jika perusahaan tidak melakukan aktivitas sosial dan lingkungan, maka dapat dipastikan tingkat pengungkapan sosial dan lingkungannya akan rendah.

\subsubsection{Pengaruh Ukuran Perusahaan Manufaktur Terhadap Pengungkapan Sosial dan Lingkungan Perusahaan Manufaktur}

Hasil penelitian ini menunjukkan bahwa ukuran perusahaan berpengaruh positif terhadap pengungkapan sosial dan lingkungan perusahaan atau dengan kata lain semakin besar ukuran suatu perusahaan, maka manajemen akan cenderung untuk melakukan lebih banyak pengungkapan kegiatan sosial dan lingkungan yang dilakukan perusahaan. Hasil penelitian ini sesuai dengan hasil penelitian Setyorini dan Ishak (2012), Galani et al. (2011), dan Lucyanda dan Siagian (2012).

Argumentasi yang dapat menjelaskan mengapa ukuran perusahaan berpengaruh positif terhadap pengungkapan sosial dan lingkungan yang dilakukan perusahaan dijelaskan oleh Setyorini dan Ishak (2012), Lucyanda dan Siagian (2012), dan Zadeh dan Eskandari (2012) yang berpendapat bahwa perusahaan yang berukuran besar dimonitoring dan diawasi oleh lebih banyak kelompok stakeholders. Manajemen perusahaan akan memerlukan usaha yang lebih besar untuk menjalin komunikasi dan hubungan dengan kelompok stakeholders yang ada. Jika perusahaan tersebut berukuran besar dan juga mendapatkan tingkat profitabilitas yang tinggi, maka akan ada tekanan dari stakeholders terkait agar manajemen perusahaan peduli terhadap isu sosial dan lingkungan. Komunikasi dan hubungan yang dilakukan oleh manajemen terhadap kelompok stakeholders merupakan suatu bentuk upaya agar perusahaan memperoleh legitimasi dari stakeholders terkait (Zadeh dan Eskandari, 2012). Bentuk komunikasi atau hubungan ini dapat dilakukan dengan meningkatkan itemitem pengungkapan sosial dan lingkungan yang harus dilakukan manajemen perusahaan.

Pendapat lain yang dapat menjelaskan hubungan positif antara ukuran perusahaan dengan luas pengungkapan sosial dan lingkungan yang dilakukan perusahaan dikemukakan oleh Watson et al. (2002) dan Galani et al. (2011). Watson et al. (2002) berpendapat bahwa perusahaan dengan ukuran besar seharusnya tidak memerlukan biaya yang terlalu besar untuk melakukan pengungkapan sukarela. Pendapat Watson et al. (2002) ini didukung oleh pendapat Galani et al. (2011) yang menyatakan bahwa perusahaan dengan ukuran besar memiliki sumber daya yang cukup untuk mengurangi biaya terkait produksi informasi yang harus diungkapkan dalam laporan tahunan. Argumentasi ini dapat menjelaskan bahwa seharusnya perusahaan dengan ukuran besar dapat melakukan pengungkapan wajib maupun pengungkapan sukarela secara lebih luas.

Perusahaan dengan ukuran yang besar memiliki tingkat visibilitas politis yang tinggi dan ini sangat berhubungan dengan luasnya pengungkapan sosial dan lingkungan yang dilakukan perusahaan (Belkaoui dan Karpik, 1989). Jones dan Jonas (2011) berpendapat bahwa salah satu motivasi manajemen untuk melakukan pengungkapan sosial dan lingkungan adalah untuk merespon perhatian stakeholders khususnya mengenai dampak sosial dan lingkungan yang diakibatkan oleh aktivitas perusahaan. Pendapat Jones dan Jonas (2011) ini didukung oleh Othman dan Ameer (2009) yang melihat bahwa perusahaan dengan ukuran besar memiliki biaya politis yang tinggi (political cost theory) sehingga memiliki motivasi yang tinggi untuk melakukan pengungkapan sosial dan lingkungan. Biaya politis yang tinggi ini disebabkan karena aktivitas operasional memiliki dampak kerusakan lingkungan sehingga manajemen perusahaan perlu melakukan beberapa upaya untuk mengurangi dampak lingkungan tersebut. Tentu saja ini merupakan biaya tambahan yang harus dikeluarkan oleh manajemen perusahaan. Upaya-upaya yang dilakukan oleh manajemen perusahaan untuk 
mengurangi dampak lingkungan tersebut akan diungkapkan dalam laporan tahunan dengan tujuan agar biaya politis yang dihadapi perusahaan dapat berkurang. Chariri (2008) berpendapat bahwa pengungkapan sukarela yang dilakukan manajemen perusahaan dalam laporan tahunan merupakan usaha yang dilakukan untuk mengurangi biaya politis yang harus ditanggung perusahaan akibat dampak-dampak dari aktivitas perusahaan.

\subsubsection{Pengaruh Manajemen Laba Terhadap Pengungkapan Sosial dan Lingkungan Perusahaan Manufaktur}

Hasil penelitian ini menunjukkan bahwa manajemen yang melakukan manajemen laba tidak menjadikan pengungkapan sosial dan lingkungan perusahaan sebagai alat untuk mengacaukan monitoring dari stakeholders terhadap rekayasa laba yang dilakukan oleh manajemen. Hasil penelitian ini mendukung hasil penelitian Sun et al. (2010) yang menjelaskan bahwa manajer-manajer perusahaan di Inggris tidak menggunakan pengungkapan sosial dan lingkungan sebagai alat atau teknik untuk mengurangi kemungkinan adanya monitoring dari stakeholders terhadap praktek manajemen laba di perusahaan. Hasil penelitian ini tidak sejalan dengan pendapat Oktafia (2013) yang berpendapat bahwa manajer yang memiliki perilaku oportunistik akan cenderung menjalin hubungan dengan stakeholders lain melalui pengungkapan sosial sebagai strategi untuk mempertahankan jabatan dan menghindarkan monitoring atas praktek manajemen laba yang dilakukan oleh manajemen.

Hasil penelitian ini tidak mendukung pendapat Rahmawati dan Dianita (2011) yang berpendapat bahwa pengungkapan sosial dan lingkungan sebagai bentuk mekanisme pertahanan diri manajer dari tekanan stakeholders terhadap praktek manajemen laba yang dilakukan oleh manajemen. Hasil ini menjelaskan ada cara-cara lain yang dipergunakan manajemen, bukan dengan pengungkapan sosial dan lingkungan, untuk mengurangi monitoring stakeholders terhadap rekayasa laba yang dilakukan oleh manajemen.

\subsubsection{Pengaruh Profitabilitas Perusahaan Manufaktur Terhadap Pengungkapan Sosial dan Lingkungan Perusahaan Manufaktur dengan Mekanisme Corporate Governance Sebagai Variabel Pemoderasi}

Hasil penelitian ini menunjukkan bahwa suatu perusahaan yang memiliki tingkat profitabilitas yang tinggi dengan status kepemilikan manajerial yang tinggi tidak mendorong manajemen perusahaan untuk lebih mengungkapkan informasi sosial dan lingkungan perusahaan. Dengan kata lain kepemilikan manajerial yang tinggi tidak memberikan motivasi kepada manajemen untuk melakukan pengungkapan sosial dan lingkungan meskipun perusahaan memiliki profitabilitas yang tinggi. Dengan demikian maka dapat dikatakan kepemilikan manajerial bukan merupakan salah satu infrastruktur pendukung adanya pengungkapan sosial dan lingkungan perusahaan. Hasil penelitian ini tidak sesuai dengan pendapat Soliman et al. (2012) yang menyatakan bahwa kegiatan sosial yang dilakukan perusahaan dapat meningkatkan nilai perusahaan sehingga hal ini merupakan insentif bagi manajemen untuk bersedia melakukan pengungkapan kegiatan sosial perusahaan. Manajemen perusahaan manufaktur di Indonesia yang memiliki kepemilikan dalam perusahaan tampaknya belum melihat bahwa kegiatan dan pengungkapan informasi sosial dan lingkungan dapat meningkatkan nilai perusahaan di mata stakeholders. Terlepas dari motivasi apa yang melatarbelakangi perusahaan melakukan kegiatan sosial dan lingkungan, tampaknya kegiatan tersebut dipergunakan manajemen untuk meningkatkan citra perusahaan saja di mata stakeholders.

Argumentasi lain yang dapat menjelaskan mengapa kepemilikan manajerial tidak mampu meningkatkan pengungkapan sosial dan lingkungan perusahaan meskipun profitabilitas perusahaan tinggi adalah karena rata-rata kepemilikan manajerial di perusahaan 
manufaktur di Indonesia sangat rendah, yaitu hanya 2,36\% dari total kepemilikan perusahaan (lampiran tabel hasil statistik deskriptif). Kepemilikan manajerial yang rendah ini menunjukkan bahwa manajemen tidak bisa memaksakan kepentingannya sendiri dalam pengelolaan perusahaan dan harus menyamakan kepentingannya dengan kepentingan pemilik perusahaan. Mungkin saja dalam menjalankan aktivitas perusahaan, manajemen memiliki inisiatif untuk melakukan kegiatan dan pengungkapan informasi sosial dan lingkungan. Jika pemilik perusahaan belum menganggap bahwa kegiatan sosial dan lingkungan merupakan suatu hal yang penting bagi perusahaan, keinginan manajemen ini bisa tidak terlaksana. Hal ini dapat dipahami jika pemilik perusahaan beranggapan bahwa biaya yang dikeluarkan perusahaan untuk melaksanakan kegiatan sosial dan lingkungan dapat mengurangi laba perusahaan.

Argumentasi berikutnya yang dapat menjelaskan hasil penelitian ini adalah dalam tata kelola perusahaan manufaktur di Indonesia tidak terdapat bonus kepada manajemen perusahaan jika kinerja sosial atau lingkungan perusahaan mengalami peningkatan. Salah satu ketentuan dalam item-item indikator GRI 2002 mensyaratkan adanya bonus kepada manajemen perusahaan yang pemberiannya dinilai berdasarkan kinerja sosial dan lingkungan perusahaan. Tidak adanya sistem kompensasi seperti ini menunjukkan bahwa kompensasi atau bonus yang diberikan manajemen masih terbatas pada pencapaian kinerja keuangan perusahaan. Hal ini dapat dimaklumi mengingat kesadaran pemilik perusahaan terhadap isu sosial dan lingkungan masih rendah sehingga kinerja perusahaan dalam bidang sosial dan lingkungan belum terlalu diperhatikan.

Mekanisme corporate governance yang lain, misalnya kepemilikan institusional, keberadaan komisaris independen, dan keberadaan komite audit juga tampaknya belum mampu mendukung peningkatan pengungkapan sosial dan lingkungan perusahaan meskipun profitabilitas perusahaan meningkat. Hal ini dikarenakan paradigma pengelolaan perusahaan masih terfokus pada hasil pencapaian kinerja keuangan perusahaan.

\subsubsection{Pengaruh Struktur Modal Perusahaan Manufaktur Terhadap Pengungkapan Sosial dan Lingkungan Perusahaan Manufaktur dengan Mekanisme Corporate Governance Sebagai Variabel Pemoderasi}

Hasil penelitian ini menunjukkan bahwa kepemilikan institusional yang tinggi belum mampu berperan sebagai infrastruktur pendukung atau memperkuat pengungkapan sosial dan lingkungan perusahaan manufaktur di Indonesia. Hasil penelitian ini tidak mendukung pendapat Aguilera et al. (2007), Beurden dan Gössling (2008), Huang (2010), dan Ali dan Rizwan (2013) yang berpendapat bahwa investor institusional atau kepemilikan institusional yang tinggi dalam perusahaan mempunyai pengaruh besar dalam pengungkapan sosial perusahaan. Hasil penelitian ini juga menunjukkan bahwa investor institusional perusahaan manufaktur di Indonesia masih memonitor dan mengawasi manajemen agar kinerja manajemen mampu menjaga pencapaian kinerja keuangan perusahaan dan menjaga rasiorasio keuangan perusahaan.

Argumentasi yang dapat mendukung hasil penelitian ini adalah investor institusional perusahaan manufaktur di Indonesia lebih mendorong manajemen perusahaan untuk menjaga rasio-rasio keuangan agar tidak melanggar perjanjian atau kontrak hutang dengan kreditur daripada mendorong manajemen untuk melakukan pengungkapan kegiatan sosial dan lingkungan. Hal ini didukung oleh hasil penelitian ini pada hipotesis 2 yang menemukan bahwa tingkat rasio solvabilitas perusahaan berbanding terbalik dengan tingkat pengungkapan sosial dan lingkungan perusahaan. Manajemen perusahaan akan melakukan pengungkapan sosial dan lingkungan jika rasio solvabilitas perusahaan rendah. Argumentasi ini tidak mendukung pendapat Jones dan Jonas (2011) yang berpendapat bahwa motivasi manajemen untuk melakukan pengungkapan sosial dan lingkungan adalah untuk 
menunjukkan keinginan yang kuat dari manajemen untuk memenuhi persyaratan dalam kontrak pinjaman.

Mekanisme corporate governance yang lain, yaitu kepemilikan manajerial, keberadaan komisaris independen, dan keberadaan komite audit tampaknya belum mendukung pengungkapan sosial dan lingkungan perusahaan meskipun rasio solvabilitas perusahaan rendah. Hal ini mungkin karena paradigma manajemen yang berpendapat bahwa meskipun perusahaan mendapatkan monitoring atau pengawasan yang ketat akibat rasio hutang/modal yang tinggi, melakukan pengungkapan sosial dan lingkungan yang lebih luas bukan merupakan cara untuk mengatasi permasalahan monitoring atau pengawasan ini. Satusatunya cara untuk mengatasi permasalahan monitoring atau pengawasan ini adalah dengan tetap menjaga rasio-rasio keuangan agar sesuai dengan kontrak hutang.

\subsubsection{Pengaruh Ukuran Perusahaan Manufaktur Terhadap Pengungkapan Sosial dan Lingkungan Perusahaan Manufaktur dengan Mekanisme Corporate Governance Sebagai Variabel Pemoderasi}

Hasil penelitian ini menunjukkan bahwa mekanisme corporate governance yang ada di perusahaan manufaktur, baik perusahaan manufaktur dengan ukuran besar atau kecil, tidak memberikan dukungan terhadap pengungkapan sosial dan lingkungan perusahaan. Dengan kata lain dapat dikatakan bahwa tidak ada peran sama sekali dari mekanisme corporate governance yang ada di perusahaan terhadap pengungkapan sosial dan lingkungan yang harus dilakukan perusahaan. Hal ini berimplikasi bahwa pengungkapan sosial dan lingkungan yang dilakukan perusahaan tidak dilihat dari mekanisme corporate governance yang ada, melainkan dari sejauh mana stakeholders melakukan pengawasan dan monitoring terhadap aktivitas perusahaan. Jika stakeholders melakukan pengawasan yang ketat terhadap aktivitas perusahaan, maka mungkin saja pengungkapan sosial dan lingkungan perusahaan akan meningkat. Hal ini menunjukkan bahwa motivasi pengungkapan sosial dan lingkungan yang dilakukan perusahaan tidak bersumber dari pihak internal perusahaan, melainkan dari pihak eksternal perusahaan.

Hasil penelitian ini mendukung pendapat Chariri (2008) yang menyatakan bahwa tipe pengungkapan sosial dan lingkungan yang dilakukan manajemen sangat ditentukan oleh kelompok stakeholders yang melakukan monitoring atau pengawasan terhadap aktivitas perusahaan. Semakin banyak kelompok stakeholders yang melakukan monitoring atau pengawasan, maka manajemen akan berusaha memperluas pengungkapan sosial dan lingkungan perusahaan, tidak perduli seperti apa mekanisme corporate governance yang ada di perusahaan.

Argumentasi lain yang dapat digunakan menjelaskan hasil ini adalah bahwa manajemen perusahaan berupaya untuk mencari pembenaran dari sudut pandang stakeholders dalam menjalankan operasional perusahaan. Dilihat berdasarkan sudut pandang teori stakeholder, maka manajemen perusahaan harus mampu untuk memenuhi semua keinginan dan kepentingan stakeholders. Mallin (2004) berpendapat bahwa perusahaan beroperasi dalam komunitas sosial yang luas dan tidak hanya dalam ruang lingkup internal perusahaan. Hal ini akan membuat aktivitas perusahaan yang berukuran besar dapat dilihat dari berbagai macam sudut pandang kelompok stakeholders. Kelompok-kelompok stakeholders inilah yang akan menimbulkan adanya "kewajiban sosial” bagi perusahaan.

\subsubsection{Pengaruh Manajemen Laba Terhadap Pengungkapan Sosial dan Lingkungan Perusahaan Manufaktur dengan Mekanisme Corporate Governance Sebagai Variabel Pemoderasi}

Hasil penelitian ini menunjukkan bahwa mekanisme corporate governance yang ada di perusahaan manufaktur tidak mendukung pengaruh manajemen laba terhadap 
pengungkapan sosial dan lingkungan perusahaan. Hasil ini juga mendukung hasil pengujian untuk hipotesis 4 yang menyatakan bahwa tidak terdapat pengaruh manajemen laba terhadap pengungkapan sosial dan lingkungan perusahaan. Hasil penelitian ini mendukung hasil penelitian Oktafia (2013) yang menyatakan bahwa komisaris independen dan dewan direksi yang ada di dalam struktur organisasi perusahaan tidak mendukung pengaruh manajemen laba terhadap pengungkapan sosial dan lingkungan yang dilakukan perusahaan. Hasil penelitian ini tidak mendukung hasil lain penelitian Sun et al. (2010) dan Oktafia (2013) yang menyatakan bahwa komite audit dalam struktur organisasi perusahaan mendukung pengaruh manajemen laba terhadap pengungkapan sosial dan lingkungan perusahaan. Penelitian ini tidak mendukung pendapat Oktafia (2013) yang berpendapat bahwa peran komite audit berdampak pada tindakan perusahaan dalam mempengaruhi akuntabilitas dan implementasi pengungkapan tanggung jawab sosial.

Argumentasi yang dapat menjelaskan hasil ini dikemukakan oleh Oktafia (2013) yang berpendapat bahwa mekanisme corporate governance dalam perusahaan, misalnya pengangkatan dewan komisaris independen, mungkin dilakukan oleh perusahaan hanya untuk memenuhi ketentuan regulasi saja tanpa ada maksud atau motivasi untuk benar-benar melaksanakan tata kelola perusahaan yang baik. Jika memang keberadaan dewan komisaris independen dan komite audit hanya untuk memenuhi regulasi saja, maka mungkin tata kelola perusahaan yang saat ini dilaksanakan di perusahaan manufaktur di Indonesia belum mampu untuk melaksanakan fungsi monitoring atau pengawasan terkait dengan praktek manajemen laba yang dilakukan oleh manajemen perusahaan.

\section{SIMPULAN DAN SARAN}

\subsection{Simpulan}

Simpulan yang dapat diambil berdasarkan hasil analisis dan pembahasan, yaitu

1. Profitabilitas perusahaan, struktur modal perusahaan, dan ukuran perusahaan berpengaruh terhadap pengungkapan sosial dan lingkungan yang dilakukan perusahaan manufaktur. Manajemen laba tidak berpengaruh terhadap pengungkapan sosial dan lingkungan perusahaan manufaktur.

2. Mekanisme corporate governance yang terdapat pada perusahaan manufaktur tidak mampu memperkuat pengaruh profitabilitas perusahaan, struktur modal perusahaan, ukuran perusahaan, dan manajemen laba terhadap pengungkapan sosial dan lingkungan yang dilakukan perusahaan manufaktur.

\subsection{Implikasi Penelitian}

Implikasi hasil penelitian ini bagi perusahaan adalah dapat memberikan saran dan masukan agar tata kelola perusahaan di dalam perusahaan manufaktur dapat diperbaiki. Hasil penelitian ini menunjukkan bahwa mekanisme corporate governance yang ada di perusahaan masih sangat terfokus kepada hasil-hasil kinerja keuangan perusahaan dan belum terlalu peduli dengan isu-isu eksternal di luar perusahaan, misalnya isu sosial dan lingkungan. Paradigma yang masih terfokus kepada kinerja keuangan harus segera diperbaiki. Kegiatan bisnis harus dirubah dengan memasukkan konsep corporate social responsibility sebagai bagian dari aktivitas bisnis perusahaan (Sawarjuwono, 2012).

Implikasi lain bagi perusahaan adalah adanya perubahan dalam konsep mengenai laba atau profit. Konsep profit harus dirubah dari konsep yang bersifat entitas sempit egoistis menjadi yang bersifat luas dan egaliter (Sawarjuwono, 2012). Pengeluaran-pengeluaran perusahaan untuk mempertahankan lingkungan dan menjaga kesetaraan dan keseimbangan sosial bukanlah merupakan biaya. Pengeluaran tersebut dapat diklasifikasikan sebagai pengeluaran untuk mencapai profit bagi entitas bisnis. Argumentasi ini akan menjelaskan bahwa pengeluaran dalam bidang sosial dan lingkungan bukan merupakan biaya yang 
mengurangi profit, tetap menjadi bagian dari penciptaan profit bagi entitas (Sawarjuwono, 2012). Manajemen harus menyadari bahwa keberadaan perusahaan tidak bisa lepas dari kepentingan publik secara luas. Rusdianto (2013) berpendapat bahwa manajemen tidak boleh hanya mengejar keuntungan semata, tapi juga harus menyadari bahwa aktivitas yang dijalankan perusahaan mungkin akan memiliki konsekuensi sosial dan lingkungan bagi publik. Hal inilah yang menyebabkan ada tuntutan moral bagi manajemen perusahaan untuk memperhatikan kepentingan publik, khususnya dalam bidang sosial dan lingkungan. Perusahaan juga harus menyadari bahwa akuntabilitas dalam penyampaian informasi menjadi penting karena terdapat asimetri informasi antara manajemen perusahaan dengan stakeholders (Rusdianto, 2013). Utama (2011) berpendapat bahwa akuntabilitas dapat dipenuhi dan asimetri informasi dapat dikurangi jika perusahaan melakukan pengungkapan mengenai aktivitas sosial dan lingkungannya kepada stakeholders.

Implikasi hasil penelitian ini bagi pengambil kebijakan, misalnya IAI dan KNKG, adalah memberikan bukti bahwa ternyata penerapan tata kelola perusahaan yang berjalan di perusahaan tidak dilaksanakan dengan baik. Ketentuan-ketentuan yang terdapat dalam Pedoman Umum Good Corporate Governance Indonesia yang mengatur mengenai tanggung jawab sosial dan lingkungan perusahaan belum dilaksanakan oleh semua manajemen perusahaan. Salah satu asas good corporate governance, yaitu mengenai kewajaran dan kesetaraan tidak dilaksanakan oleh perusahaan. Kepentingan perusahaan terhadap stakeholders di sekitar perusahaan, misalnya masyarakat dan LSM atau organisasi lingkungan harus sama dengan kepentingan perusahaan terhadap pemegang saham dan kreditur. Informasi sosial dan lingkungan perusahaan yang harus disampaikan dari manajemen kepada stakeholders terkait harus sama kualitas dan kuantitasnya dengan informasi kinerja perusahaan yang disampaikan kepada pemegang saham. Hal ini akan mengakibatkan adanya kewajaran dan kesetaraan dalam pengungkapan informasi oleh manajemen perusahaan.

\subsection{Saran}

Hasil penelitian ini diharapkan dapat menjadi sumber ide dan masukan bagi pengembangan penelitian-penelitian dengan topik pengungkapan sosial dan lingkungan. Beberapa saran yang peneliti dapat berikan, yaitu pertama sampel penelitian perlu diperluas. Dalam penelitian ini, peneliti mempergunakan perusahaan manufaktur dan tidak memasukkan perusahaan yang masuk dalam industri pertambangan. Untuk penelitian di masa depan, sebaiknya memasukkan juga perusahaan-perusahaan yang masuk dalam industri yang operasionalnya berpotensi memiliki masalah terhadap lingkungan. Tujuan dari penambahan sampel ini agar hasil penelitian dapat digeneralisasikan untuk semua perusahaan mengingat tujuan dari penelitian kuantitatif adalah hasil penelitian dapat digeneralisasikan kepada semua sampel.

Penelitian selanjutnya juga dapat meneliti mengenai tipe strategi pengungkapan sosial dan lingkungan perusahaan dan dihubungkan dengan bagaimana cara manajemen perusahaan untuk mengelola stakeholders terkait dengan aktivitas sosial dan lingkungan yang dilakukan perusahaan. Penelitian selanjutnya dapat juga meneliti mengenai topik-topik sosial dan lingkungan apa yang sering diungkapkan oleh manajemen perusahaan serta motivasi manajemen untuk melakukan pengungkapan sosial dan lingkungan. Perlu diteliti juga apakah pengungkapan mengenai kegiatan sosial dan lingkungan perusahaan murni merupakan kebijakan perusahaan atau keinginan (nilai personal) dari manajemen perusahaan. Ini akan sangat terkait dengan motivasi apa yang mendasari perusahaan untuk melakukan pengungkapan sosial dan lingkungan. Metode penelitian yang dapat dipergunakan adalah metode penelitian kualitatif. 


\section{DAFTAR PUSTAKA}

Aguilera, R., C. Williams, J. Conley, and D. Rupp. 2007. Corporate Governance and Social Responsibility: A Comparative Analysis of the UK and the US. Corporate Governance: An International Review. Vol. 14: 147-158.

Alarussi, A. S., M. M. Hanefah, and M. H. Selamat. 2009. Internet Financial and Environmental Dislcosures by Malaysian Companies. Issues in Social and Environmental Accounting. Vol. 3, No. 1, June 2009: 3-25.

Ali, W. and M. Rizwan. 2013. Factors Influencing Corporate Social and Environmental Disclosure (CSED) Practices in the Developing Countries: An Institutional Theoretical Perspective. International Journal of Asian Social Science. Vol. 3: 590-609.

Almilia, Luciana S., N. H. U. Dewi, dan V. H. I. Hartono. 2011. Faktor-Faktor yang Mempengaruhi Pengungkapan Tanggung Jawab Sosial dan Dampaknya Terhadap Kinerja Keuangan dan Ukuran Perusahaan. Fokus Ekonomi. Vol. 10, No. 1, April 2011: 50-68.

Andayani, Wuryan and Sari Atmini. 2012. Corporate Social Responsibility (CSR), Good Corporate Governance (GCG), and Firm Performance. Journal of Modern Accounting and Auditing. Vol. 8, No. 10, October 2012: 1484-1495.

Arshad, R., S. M. Mansor, and R. Othman. 2012. Market Orientation, Firm Performance and The Mediating Effect of Corporate Social Responsibility. The Journal of Applied Business Research. Vol. 28, No. 5: 851-860.

Barako, D., G. P. Hancock, and H. Y. Izan. 2006. Relationship between Corporate Governance Attributes and Voluntary Disclosures in Annual Reports: The Kenyan Experience. Financial Reporting, Regulation, and Governance, 5(1): 1-25.

Belkaoui, A. and P. G. Karpik. 1989. Determinants of The Corporate Decision to Disclose Social Information. Accounting, Auditing, \& Accountability Journal. Vol. 2, No. 1. 1989.

Beurden, P. and T. Gössling. 2008. The Worth of Values: A Literature Review on the Relation between Corporate Social and Financial Performance. Journal of Business Ethics. Vol. 82: 407-424.

Chan, C. and P. Kent. 2003. Application of Stakeholders Theory to the Quantity and Quality of Australian Voluntary Corporate Environmental Disclosures. Paper presented to the Accounting and Finance Association of Australia and New Zealand (AFAANZ), Brisbane, $6^{\text {th }}$ to $8^{\text {th }}$ July.

Chariri, A. 2008. Kritik Sosial atas Pemakaian Teori dalam Penelitian Pengungkapan Sosial dan Lingkungan. Jurnal MAKSI. Vol. 8, No. 2, Agustus 2008: 151-169.

Choe, H. and B. S. Lee. 2003. Korean Bank Governance Reform After Asian Financial Crisis. Pacific-Basin Financial Journal. Vol. 11: 483-508.

Choi, F.D.S. dan G.G. Mueller. 1998. Akuntansi Internasional. Buku Dua Edisi Ke-2. Jakarta: Penerbit Salemba Empat.

Christopher, T. and M. Filipovic. 2008. The Extent and Determinants of Disclosure of Global Reporting Initiative Guidelines: Australian Evidence. The Journal of Contemporary Issue in Business and Government. Vol. 14: 17-40.

Clarkson, Peter M., Yue Li, Gordon D. Richardson, and Florin P. Vasvari. 2007. Revisiting the Relation between Environmental Performance and Environmental Disclosure: An Empirical Analysis. Accounting, Organizations and Society: 1-25.

Collier, P. and A. Gregory. 1999. Audit Committee Activity and Agency Cost. Journal Accounting and Public Policy. Vol. 18: 311-332.

Cormier, Denis., M. J. Ledoux, and M. Magnan. 2009. Social and Environmental Disclosures: Substitutes or Complemets? ESG UQAM and Concordia University, Canada. 
David, P. and Kochhar. 1996. Barriers to Effective Corporate Governancy by Institutional Investors: Implications for Theory and Practice. European Management Journal. Vol. 14, No. 5: 457-466.

Deegan, C. M. 2007. Financial Accounting Theory ( ${ }^{\text {nd }}$ ed.). Australia: McGraw-Hill.

Denis, D. J., D. K. Denis, and A. Sarin. 1997. Agency Problems, Equity Ownership, and Corporate Diversification. The Journal of Finance. Vol. 52, No. 1: 135-160.

Ebrahim, A. 2007. Earnings Management and Board Activity: An Additional Evidence. Review of Accounting and Finance. Vol. 6, No. 1: 42-58.

Fama, E. F. and M. C. Jensen. 1983. Separation of Ownership and Control. Journal of Law and Economics. Vol. 26, No. 2: 301-325.

Galani, D., E. Gravas, and A. Stavropoulos. 2011. The Relation between Firm Size and Environmental Disclosure. International Conference on Applied Economics - ICOAE 2011: 179-186.

Ghozali, Imam. 2011. Aplikasi Analisis Multivariate dengan Program IBM SPSS 19. Semarang: Badan Penerbit Universitas Diponegoro.

Graves, S. B. and S. A. Waddock. 1994. Institutional Owners and Corporate Social Performance. Academy of Management Journal. Vol. 37: 1034-1046.

Gray, R., R. Kouhy, and S. Lavers. 1995. Corporate Social and Environmental Reporting: A Review of the Literature and A Longitudinal Study of UK Disclosure. Accounting, Auditing, and Accountability Journal. Vol. 8, No. 2: 47-77.

Huang, Chi-Jui. 2010. Corporate Governance, Corporate Social Responsibility and Corporate Performance. Journal of Management \& Organization. Vol. 16, Issue 5, November 2010: 641-655.

Indrawati, Novita. 2009. Pengungkapan Corporate Social Responsibility (CSR) dalam Annual Report serta Pengaruh Political Visibility dan Economic Performance. Pekbis Jurnal. Vol. 1, No. 1, Maret 2009: 1-11.

Jamali, D., A. M. Safieddine, and M. Rabbath. 2008. Corporate Governance and Corporate Social Responsibility Synergies and Interrelationships. Journal Compilation. Vol. 16, No. 5, September 2008: 443-459.

Jensen, M. C. and W. H. Meckling. 1976. Theory of The Firm: Manajerial Behaviour, Agency Cost, and Ownership Structure. Journal of Financial and Economics: 305-360.

Jo, H. and M. A. Harjoto. 2011. Corporate Governance and Firm Value: The Impact of Corporate Social Responsibility. Journal of Business Ethics. Vol. 103: 351-383.

Jones, Ambrose III and G. A. Jonas. 2011. Corporate Social Responsibility Reporting: The Growing Need for Input from the Accounting Profession. The CPA Journal. February, 2011: 65-71.

Kamil, A. dan A. Herusetya. 2012. Pengaruh Karakteristik Perusahaan Terhadap Luas Pengungkapan Kegiatan Corporate Social Responsibility. Media Riset Akuntansi. Vol. 2, No.1, Februari 2012: 1-17.

Klein, A. 2002. Audit Committee, Board of Director Characteristics, and Earnings Management. Journal of Accounting and Economics. Vol. 33, No. 3: 375-401.

Komite Nasional Kebijakan Governance. 2006. Pedoman Umum Good Corporate Governance Indonesia. Jakarta: Komite Nasional Kebijakan Governance.

Laan, Sandra van der. 2009. The Role of Theory in Explaining Motivation for Corporate Social Disclosures: Voluntary Disclosures vs 'Solicited' Disclosures. Australian Accounting Business and Finance Journal. Vol. 3, No. 4: 15-29.

Lasdi, Lodovicus. 2008. Perilaku Manajemen Laba Perusahaan dan Konservatisma Akuntansi: Berbeda atau Sama. Jurnal Manajemen Teori dan Terapan. Tahun 1, No, 2, Agustus 2008. 
Liana, Lie. 2009. Penggunaan MRA dengan Spss untuk Menguji Pengaruh Variabel Moderating terhadap Hubungan antara Variabel Independen dengan Variabel Dependen. Jurnal Teknologi Informasi DINAMIK. Vol. XIV, No. 2, Juli 2009: 90-97.

Lindblom, CK. 1993. The Implications of Organizational Legitimacy for Corporate Social Performance and Disclosure. Paper presented at the Critical Perspectives on Accounting Conference, New York, 1993.

Liu, D. R., L. M. Mao, S H. Li, and M. Yan. 2009. Empirical Analysis of Information Disclosure of Social Responsibilities of Listed Companies Based on the Corporate Value. Xi Tong Gong Cheng. Vol. 27, No. 2: 69-72.

Lucyanda, J. and L. G. Siagian. 2012. The Influence of Company Characteristics Toward Corporate Social Responsibility Disclosure. The 2012 International Conference on Business and Management. 6-7 September 2012, Phuket-Thailand: 601-619.

Ma, L. F. and Y. Zhao. 2009. Corporate Social Disclosure and Determinates Analysis in Listed Companies in China. Security Market Guide. Vol. 3: 3-9.

Mallin, Christine A. 2004. Corporate Governance. New York: Oxford University Press.

McConnell, J. J., and H. Servaes. 1990. Additional Evidence on Equity Ownership and Corporate Value. Journal of Financial Economics. Vol. 27: 595-612.

Mia, Parvez and Al-Abdullah-Mamun. 2011. Corporate Social Disclosure during the Global Financial Crisis. International Journal of Economics and Finance. Vol. 3, No. 6, November 2011: 174-187.

Mulyadi, M. S. and Yunita Anwar. 2012. Influence of Corporate Governance and Profitability to Corporate CSR Disclosure. International Journal of Arts and Commerce. Vol. 1, No. 7, December 2012: 29-35.

Nur, Marzully dan Denies Priantinah. 2012. Analisis Faktor-Faktor yang Mempengaruhi Pengungkapan Corporate Social Responsibility di Indonesia (Studi Empiris pada Perusahaan Berkategori High Profile yang Listing di Bursa Efek Indonesia). Jurnal Nominal. No. 1, Vol. 1, 22-34.

Nurkhin, Ahmad. 2010. Corporate Governance dan Profitabilitas, Pengaruhnya Terhadap Pengungkapan CSR Sosial Perusahaan. Jurnal Dinamika Akuntansi. Vol. 2, No. 1, Maret 2010: 46-55.

Nuryaman. 2013. The Effect of Corporate Social Responsibility Activities on Profitability and Stock Price (Studies on The Companies Listed on Indonesia Stock Exchange). $4^{\text {th }}$ International Conference on Business and Economic Research (4 ${ }^{\text {th }}$ ICBER 2013) Proceeding: 756-769.

Oktafia, Yufenti. 2013. Pengaruh Manajemen Laba Terhadap Pengungkapan Tanggung Jawab Sosial Perusahaan dengan Corporate Governance Sebagai Variabel Moderasi. Jurnal Ilmiah Akuntansi dan Humanika. Vol. 2, No. 2, Juni 2013: 676-704.

Othman, R. and R. Ameer. 2009. Corporate Social and Environmental Reporting: Where are We Heading? A Survey of Literature. International Journal of Disclosure and Governance. Vol. 6, No. 4: 298-320.

Palepu, Krishna G. and Paul M. Healy. 2013. Business Analysis and Valuation Using Financial Statements. $5^{\text {th }}$ edition. United States: South-Western, Cengage Learning.

Prior, D., J. Surroca, and J. A. Tribo. 2007. Earnings Management and Corporate Social Responsibility. Working Paper 06-23, Business Economics Series 06, September 2007.

Rahmawati and P. S. Dianita. 2011. Analysis of the Effect of Corporate Social Responsibility on Financial Performance With Earnings Management as a Moderating Variable. Journal of Modern Accounting and Auditing. Vol. 7, No. 10, October 2011: 1034-1045. 
Retno, Reny Dyah dan Denies Priantinah. 2012. Pengaruh Good Corporate Governance dan Pengungkapan Corporate Social Responsibility Terhadap Nilai Perusahaan (Studi Empiris pada Perusahaan yang Terdaftar di Bursa Efek Indonesia Periode 2007-2010). Jurnal Nominal. Volume 1, Nomor 1, Tahun 2012: 84-103.

Rusdianto, Ujang. 2013. CSR Communications A Framework for PR Practitioners. Yogyakarta: Graha Ilmu.

Sawarjuwono, Tjiptohadi. 2012. Aspek Perilaku Manusia dalam Dunia Akuntansi (Akuntansi Keperilakuan). Surabaya: Airlangga University Press.

Schipper, K. 1989. Commentary on Earnings Management. Accounting Horizons 3: 91-102.

Setyarini dan Lilik Purwanti. 2011. Mekanisme Corporate Governance, Manajemen Laba, dan Kinerja Perusahaan (Studi Empiris Pada Perusahaan yang Terdaftar di BEI). Jurnal Ilmiah Akuntansi dan Humanika. Vol. 1, No. 1, Desember 2011.

Setyorini, Christina Tri and Zuaini Ishak. 2012. Corporate Social and Environmental Disclosure: A Positive Accounting Theory View Point. International Journal of Business and Social Science. Vol. 3, No. 9, Mei 2012: 152-164.

Sharma, S., Richard M. Durand, and Oded Gur-Arie. 1981. Identification and Analysis of Moderator Variables. Journal of Marketing Research. Vol. XVIII (August 1981): 291300.

Soetedjo, Soegeng. 2009. Pembahasan Pokok-Pokok Pikiran Teori Akuntansi Vernon Kam. Surabaya: Airlangga University Press.

Soetedjo, Soegeng. 2009. Teori Akuntansi Keuangan (Teori Akuntansi Positif) Konsekuensi Ekonomi dan Penyusunan Standar Akuntansi Keuangan. Surabaya: Airlangga University Press.

Soliman, M. M., M. B. El Din, and A. Sakr. 2012. Ownership Structure and Corporate Social Responsibility (CSR): An Empirical Study of the Listed Companies in Egypt. The International Journal of Social Sciences. Vol. 5, No. 1, December 2012: 63-74.

Subramanyam, K. R. and J. J. Wild. 2008. Financial Statement Analysis. $10^{\text {th }}$ edition. New York: Mc Graw Hill.

Sun, Nan, A. Salama, K. Hussainey, and M. Habbash. 2010. Corporate Environmental Disclosure, Corporate Governance, and Earnings Management. Managerial Auditing Journal. Vol. 25, No. 7, 2010: 679-700.

Sutantoputra, Aries Widiarto. 2009. Social Disclosure Rating System for Assessing Firm's CSR Reports. Corporate Communications: An International Journal. Vol. 14, No. 1: 3448.

Teoh, H. Y. and G. Y. Shiu. 1990. Attitudes Towards Corporate Social Responsibility and Perceived Importance of Social Responsibility Information Characteristics in A Decision Context. Journal of Business Ethics. Vol. 9: 71-77.

Terzaghi, Muhammad Titan. 2012. Pengaruh Earnings Management dan Mekanisme Corporate Governance Terhadap Pengungkapan Tanggung Jawab Sosial Perusahaan Manufaktur yang Terdaftar di Bursa Efek Indonesia. Jurnal Ekonomi dan Informasi Akuntansi. Vol. 2, No. 1 Januari 2012.

Trihendradi, Cornelius. 2007. Statistik Inferen Menggunakan SPSS. Yogyakarta: Penerbit Andi.

Utama, Sidharta. 2011. An Evaluation of Support Infrastructures for Corporate Responsibility Reporting In Indonesia. Asian Business \& Management. Vol. 10, No. 3: 405-424.

Wahyuningtyas, Rr. Wulan dan Yeterina Widi Nugrahanti. 2010. Pengaruh Mekanisme Corporate Governance Terhadap Pengungkapan Corporate Social Responsibility. Fakultas Ekonomika dan Bisnis Universitas Kristen Satya Wacana.

Watson, A., P. Shrives, and C. Marston. 2002. Voluntary Disclosure of Accounting Ratios in the UK. The British Accounting Review. Vol. 34: 289-313. 
Watts, R. L. and J. L. Zimmerman. 1990. Positive Accounting Theory: A Ten Year Perspective. The Accounting Review. Vol. 65, No. 1 (Jan., 1990): 131-156.

1978. Towards A Positive Theory of Determination of Accounting Standards. The Accounting Review. Vol. 53, No. 1: 112-134.

Wijaya, Maria. 2012. Faktor-Faktor yang Mempengaruhi Pengungkapan Tanggung Jawab Sosial pada Perusahaan Manufaktur yang Terdaftar di Bursa Efek Indonesia. Jurnal Ilmiah Mahasiswa Akuntansi. Vol. 1, No. 1, Januari 2012: 26-30.

Xie, B., D. Davidson, and P. J. DaDalt. 2003. Earnings Management and Corporate Governance: The Role of the Board and the Audit Committee. Journal of Corporate Finance. Vol. 9: 295-316.

Zadeh, F. O. and A. Eskandari. 2012. Firm Size As Company's Characteristic and Level of Risk Disclosure: Review on Theories and Literatures. International Journal of Business and Social Science. Vol. 3, No. 17, September 2012.

Zarkasyi, Moh. Wahyudin. 2008. Good Corporate Governance: pada Badan Usaha Manufaktur, Perbankan, dan Jasa Keuangan Lainnya. Bandung: Alfabeta. 
Lampiran sampel perusahaan manufaktur

\begin{tabular}{|c|c|c|}
\hline No & Nama Perusahaan & Kode Perusahaan \\
\hline 1 & PT. Indocement Tunggal Prakasa Tbk. & INTP \\
\hline 2 & PT. Holcim Indonesia Tbk. & SMCB \\
\hline 3 & PT. Semen Indonesia (Persero) Tbk. & SMGR \\
\hline 4 & PT. Asahimas Flat Glass Tbk. & AMFG \\
\hline 5 & PT. Arwana Citra Mulia Tbk. & ARNA \\
\hline 6 & PT. Keramika Indonesia Asosiasi Tbk. & KIAS \\
\hline 7 & PT. Mulia Industrindo Tbk. & MLIA \\
\hline 8 & PT. Surya Toto Indonesia Tbk. & TOTO \\
\hline 9 & PT. Alakasa Industrindo Tbk. & ALKA \\
\hline 10 & PT. Alumindo Light Metal Industry Tbk. & ALMI \\
\hline 11 & PT. Beton Jaya Manunggal Tbk. & BTON \\
\hline 12 & PT. Gunawan Dianjaya Steel Tbk. & GDST \\
\hline 13 & PT. Indal Aluminium Industry Tbk. & INAI \\
\hline 14 & PT. Jaya Pari Steel Tbk. & JPRS \\
\hline 15 & PT. Lion Metal Works Tbk. & LION \\
\hline 16 & PT. Lionmesh Prima Tbk. & LMSH \\
\hline 17 & PT. Budi Acid Jaya Tbk. & BUDI \\
\hline 18 & PT. Duta Pertiwi Nusantara Tbk. & DPNS \\
\hline 19 & PT. Ekadharma International Tbk. & EKAD \\
\hline 20 & PT. Eterindo Wahanatama Tbk. & ETWA \\
\hline 21 & PT. Sorini Agro Asia Corporindo Tbk. & SOBI \\
\hline 22 & PT. Indo Acidatama Tbk. & SRSN \\
\hline 23 & PT. Alam Karya Unggul Tbk. & AKKU \\
\hline 24 & PT. Asiaplast Industries Tbk. & APLI \\
\hline 25 & PT. Berlina Tbk. & BRNA \\
\hline 26 & PT. Sekawan Intipratama Tbk. & SIAP \\
\hline 27 & PT. Trias Sentosa Tbk. & TRST \\
\hline 28 & PT. Yana Prima Hasta Persada Tbk. & YPAS \\
\hline 29 & PT. Charoen Pokphand Indonesia Tbk. & CPIN \\
\hline 30 & PT. Japfa Comfeed Indonesia Tbk. & JPFA \\
\hline 31 & PT. Malindo Feedmil Tbk. & MAIN \\
\hline 32 & PT. Siearad Produce Tbk. & SIPD \\
\hline 33 & PT. Tirta Mahakam Resources Tbk. & TIRT \\
\hline 34 & PT. Fajar Surya Wisesa Tbk. & FASW \\
\hline 35 & PT. Kertas Basuki Rachmat Indonesia Tbk. & KBRI \\
\hline 36 & PT. Astra International Tbk. & ASII \\
\hline 37 & PT. Astra Otoparts Tbk. & AUTO \\
\hline 38 & PT. Gajah Tunggal Tbk. & GJTL \\
\hline 39 & PT. Indomobil Sukses International Tbk. & IMAS \\
\hline 40 & PT. Indospring Tbk. & INDS \\
\hline 41 & PT. Multi Prima Sejahtera Tbk. & LPIN \\
\hline 42 & PT. Nipress Tbk. & NIPS \\
\hline 43 & PT. Prima Alloy Steel Universal Tbk. & PRAS \\
\hline 44 & PT. Selamat Sempurna Tbk. & SMSM \\
\hline 45 & PT. Eratex Djaya Tbk. & ERTX \\
\hline 46 & PT. Pan Brothers Tbk. & PBRX \\
\hline
\end{tabular}




\begin{tabular}{|l|l|c|}
\hline 47 & PT. Ricky Putra Globalindo Tbk. & RICY \\
\hline 48 & PT. Nusantara Inti Corpora Tbk. & UNIT \\
\hline 49 & PT. Sumi Indo Kabel Tbk. & IKBI \\
\hline 50 & PT. Jembo Cable Company Tbk. & JECC \\
\hline 51 & PT. KMI Wire and Cable Tbk. & KBLI \\
\hline 52 & PT. Kabelindo Murni Tbk. & KBLM \\
\hline 53 & PT. Supreme Cable Manufacturing and Commerce Tbk. & SCCO \\
\hline 54 & PT. Voksel Electric Tbk. & VOKS \\
\hline 55 & PT. Akasha Wira International Tbk. & ADES \\
\hline 56 & PT. Tiga Pilar Sejahtera Food Tbk. & AISA \\
\hline 57 & PT. Delta Djakarta Tbk. & DLTA \\
\hline 58 & PT. Indofood Sukses Makmur Tbk. & INDF \\
\hline 59 & PT. Multi Bintang Indonesia Tbk. & MLBI \\
\hline 60 & PT. Prashida Aneka Niaga Tbk. & PSDN \\
\hline 61 & PT. Sekar Laut Tbk. & SKLT \\
\hline 62 & PT. Ultrajaya Milk Industry and Trading Company Tbk. & ULTJ \\
\hline 63 & PT. Gudang Garam Tbk. & GGRM \\
\hline 64 & PT. Handjaya Mandala Sampoerna Tbk. & HMSP \\
\hline 65 & PT. Bentoel International Investama Tbk. & RMBA \\
\hline 66 & PT. Darya Varia Laboratoria Tbk. & DVLA \\
\hline 67 & PT. Indofarma (Persero) Tbk. & INAF \\
\hline 68 & PT. Kimia Farma (Persero) Tbk. & KAEF \\
\hline 69 & PT. Kalbe Farma Tbk. & KLBF \\
\hline 70 & PT. Merck Tbk. & MERK \\
\hline 71 & PT. Pyridam Farma Tbk. & PYFA \\
\hline 72 & PT. Mandom Indonesia Tbk. & TCID \\
\hline 73 & PT. Unilever Indonesia Tbk. & KDSI \\
\hline 74 & PT. Kedawung Setia Industri Tbk. & \\
\hline
\end{tabular}

Hasil statistik deskriptif

\begin{tabular}{|c|c|c|c|c|c|}
\hline Variabel & $\mathrm{N}$ & Minimum & Maksimum & Mean & Std. Deviation \\
\hline DACC & 370 & $-0,4209$ & 1,5742 & 0,000000 & 0,1459204 \\
CSED & 370 & 0,0112 & 0,6742 & 0,294566 & 0,1630212 \\
ROA & 370 & $-0,7558$ & 1,3439 & 0,080524 & 0,1433840 \\
KM & 370 & 0,0000 & 0,3840 & 0,023629 & 0,0593398 \\
KI & 370 & 0,2490 & 0,9982 & 0,712137 & 0,1842572 \\
LEV & 370 & 0,0395 & 2,7881 & 0,495583 & 0,3052273 \\
SIZE & 370 & 23,0825 & 32,8365 & 27,749314 & 1,6105047 \\
CG & 370 & $-4,74897$ & 1,15007 & 0,0000000 & 1,00000000 \\
ROAXCG & 370 & $-1,0901$ & 0,9166 & 0,010319 & 0,1353539 \\
LEVXCG & 370 & $-2,6303$ & 0,8646 & 0,029064 & 0,4645160 \\
SIZEXCG & 370 & $-131,7762$ & 34,0537 & 0,253230 & 26,9342193 \\
DACCXCG & 370 & $-1,0031$ & 1,0736 & $-0,003381$ & 0,1209955 \\
Valid N & 370 & & & & \\
(listwise) & & & & & \\
\hline
\end{tabular}

Sumber: Data olahan SPSS, 2014. 
Hasil uji heteroskedastisitas

Model 1.1 $\operatorname{CSED}=\alpha+\beta_{1} \mathrm{ROA}+\mathrm{e}$

Scatterplot

Dependent Variable: CSED

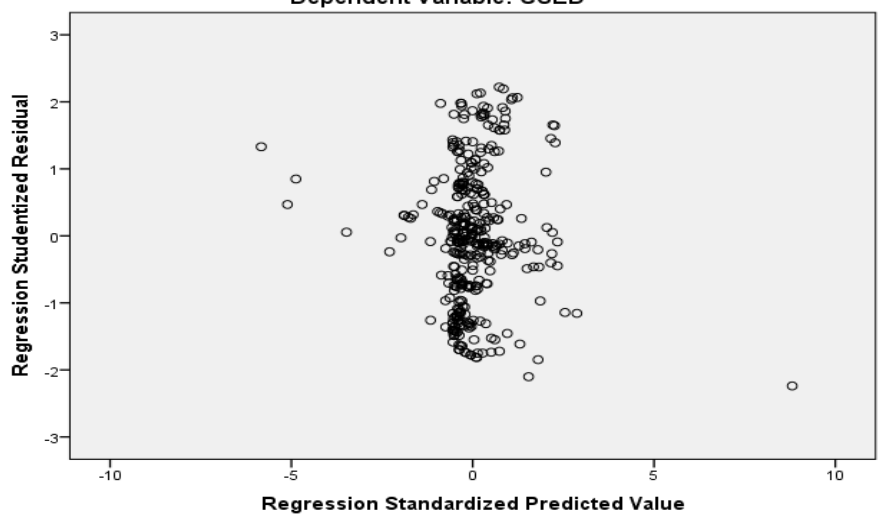

Model 1.2 $\mathrm{CSED}=\alpha+\beta_{1} \mathrm{ROA}+\beta_{2} \mathrm{CG}+\mathrm{e}$

Scatterplot

Dependent Variable: CSED

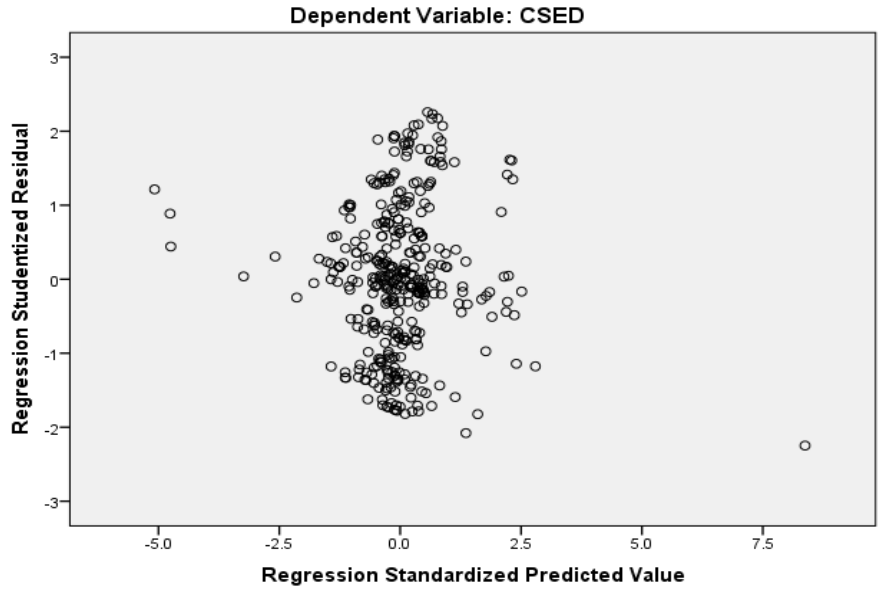

Model 1.3 $\mathrm{CSED}=\alpha+\beta_{1} \mathrm{ROA}+\beta_{2} \mathrm{CG}+\beta_{3} \mathrm{ROA} * \mathrm{CG}+\mathrm{e}$

Scatterplot

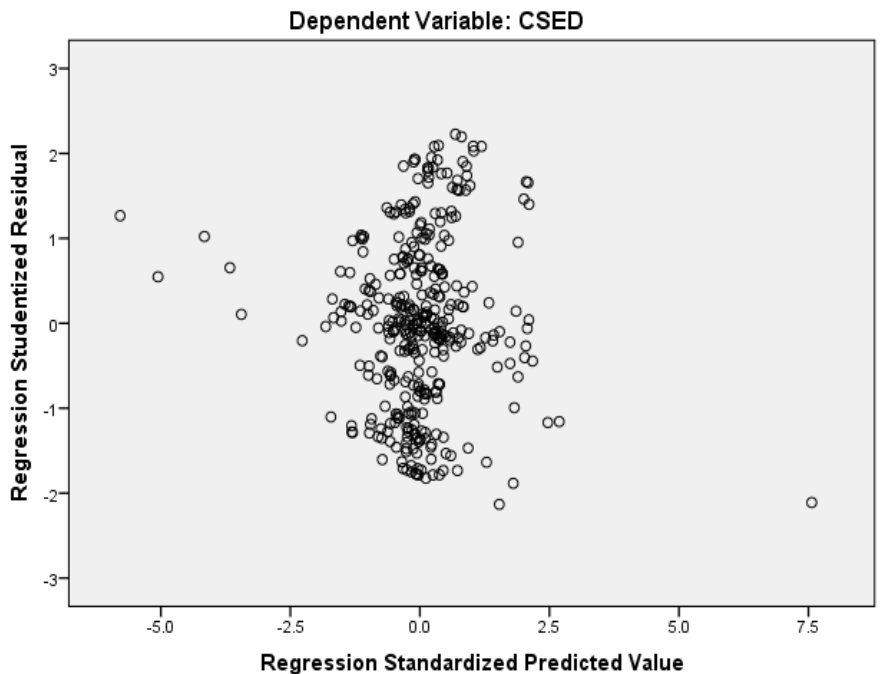


Model 2.1 CSED $=\alpha+\beta_{1} \mathrm{LEV}+\mathrm{e}$

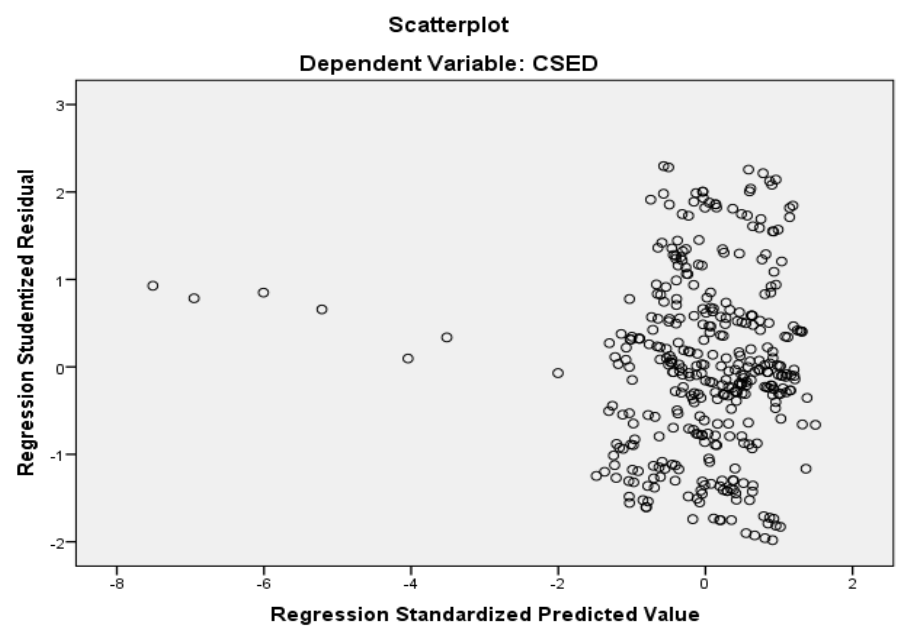

Model 2.2 $\mathrm{CSED}=\alpha+\beta_{1} \mathrm{LEV}+\beta_{2} \mathrm{CG}+\mathrm{e}$

Scatterplot

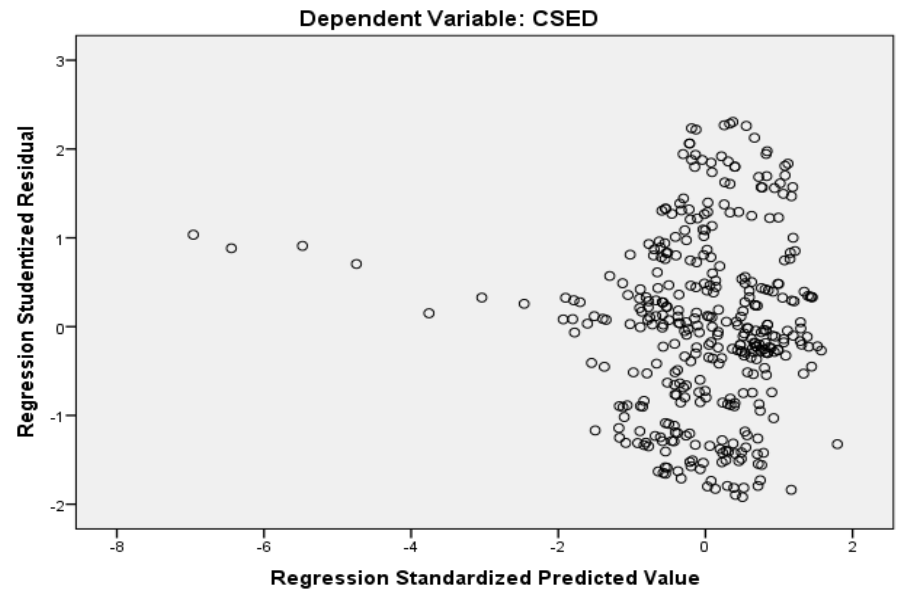

Model 2.3 $\mathrm{CSED}=\alpha+\beta_{1} \mathrm{LEV}+\beta_{2} \mathrm{CG}+\beta_{3} \mathrm{LEV} * \mathrm{CG}+\mathrm{e}$

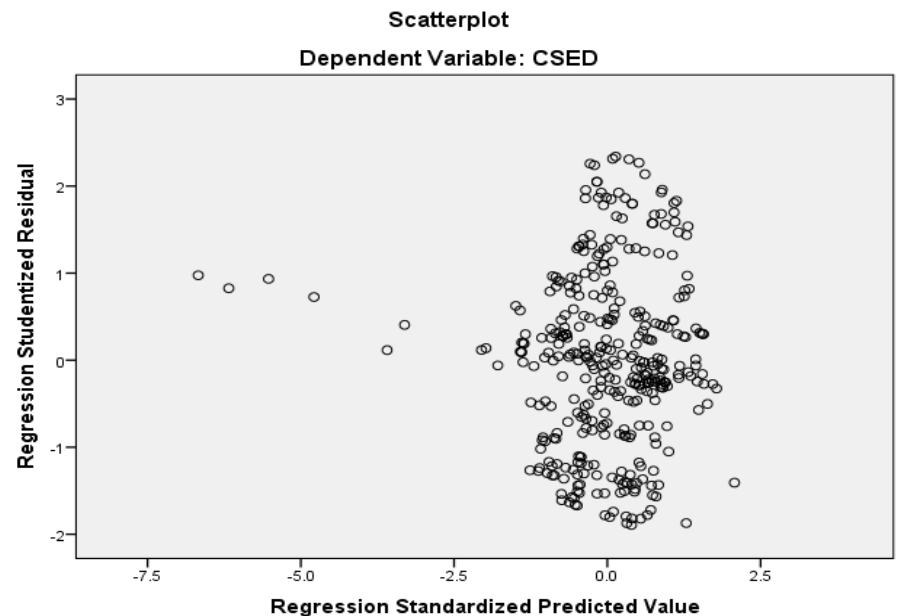


Model 3.1 CSED $=\alpha+\beta_{1}$ SIZE $+\mathrm{e}$

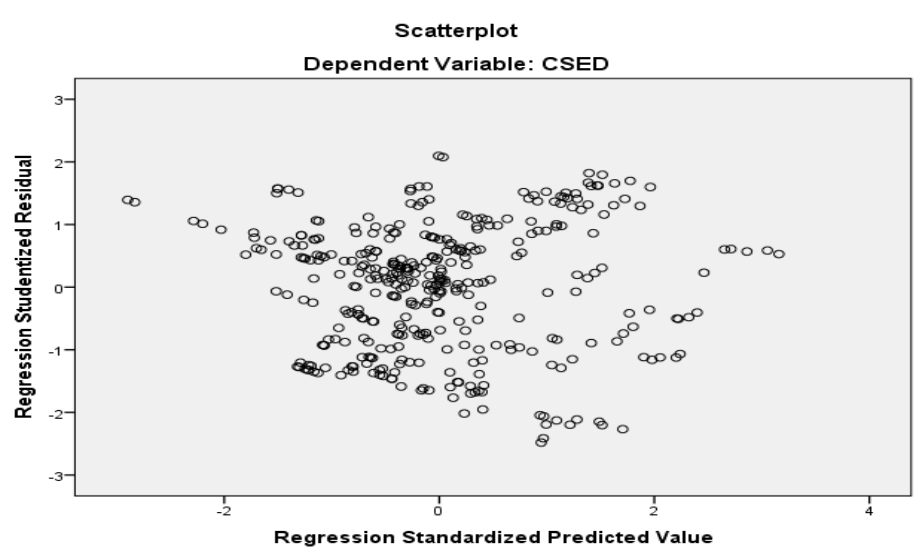

Model 3.2 CSED $=\alpha+\beta_{1}$ SIZE $+\beta_{2} \mathrm{CG}+\mathrm{e}$

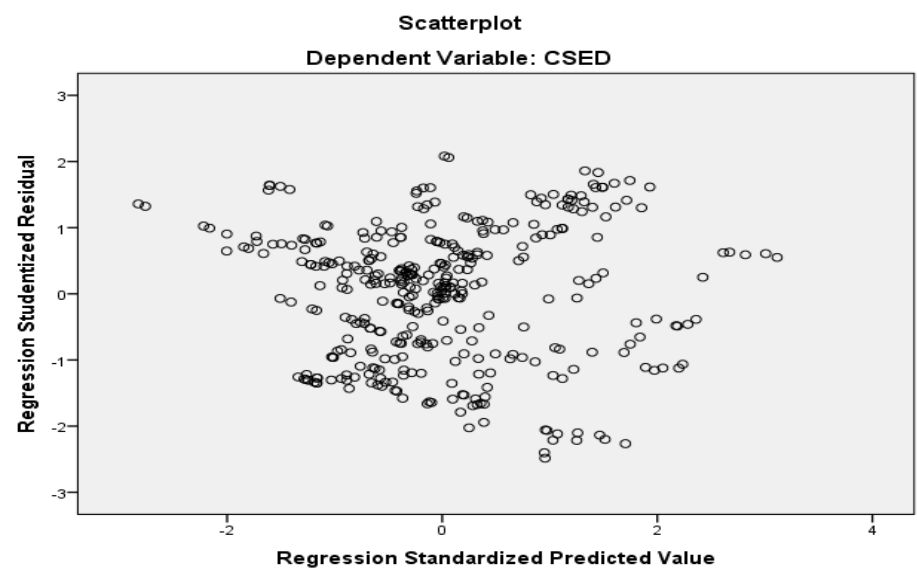

Model 3.3 $\mathrm{CSED}=\alpha+\beta_{1} \mathrm{SIZE}+\beta_{2} \mathrm{CG}+\beta_{3} \mathrm{SIZE} * \mathrm{CG}+\mathrm{e}$

Scatterplot

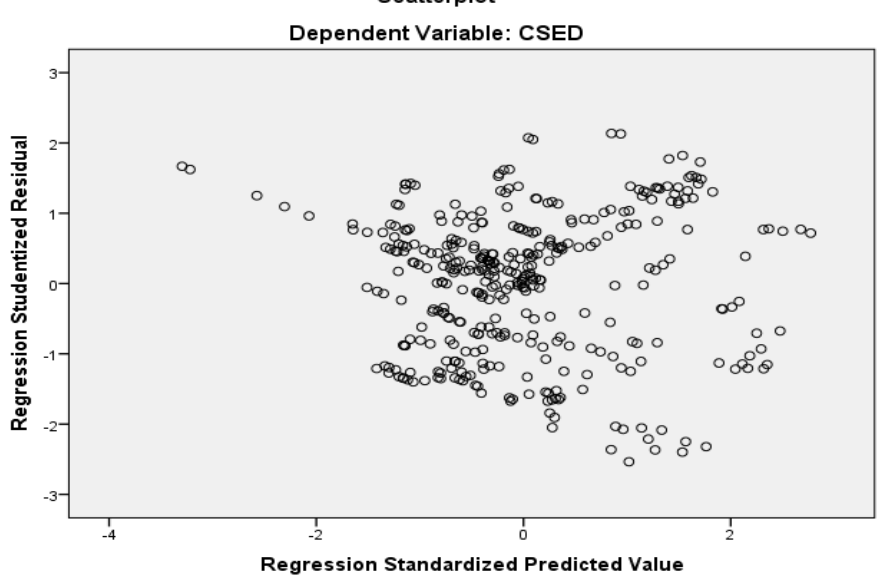


Model 4.1 CSED $=\alpha+\beta_{1}$ DACC $+\mathrm{e}$

Scatterplot

Dependent Variable: CSED

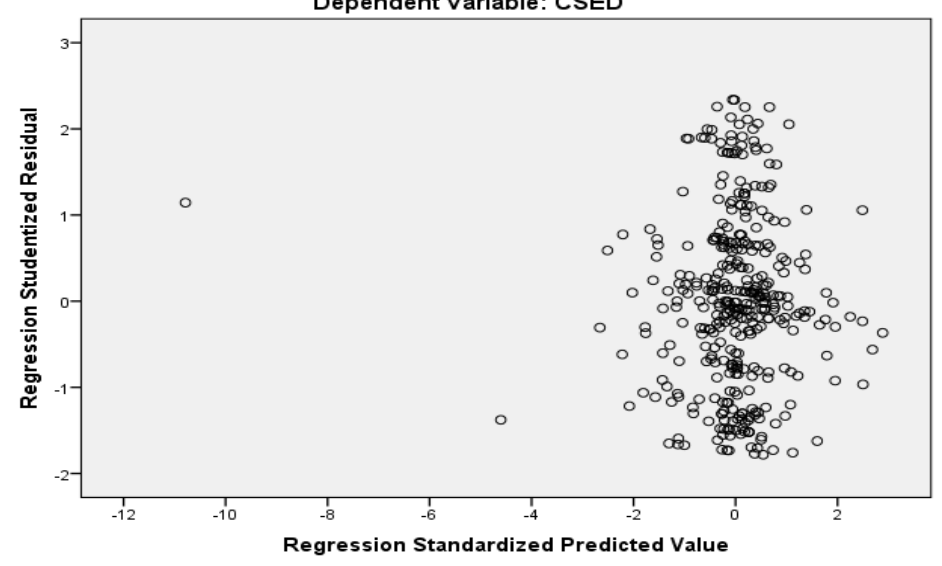

Model 4.2 $\mathrm{CSED}=\alpha+\beta_{1} \mathrm{DACC}+\beta_{2} \mathrm{CG}+\mathrm{e}$

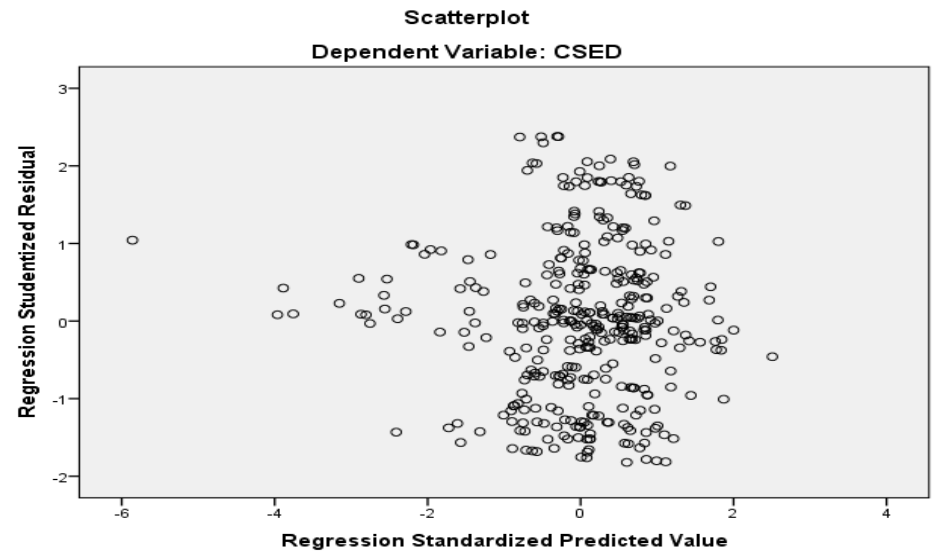

Model 4.3 CSED $=\alpha+\beta_{1} \mathrm{DACC}+\beta_{2} \mathrm{CG}+\beta_{3} \mathrm{DACC} * \mathrm{CG}+\mathrm{e}$

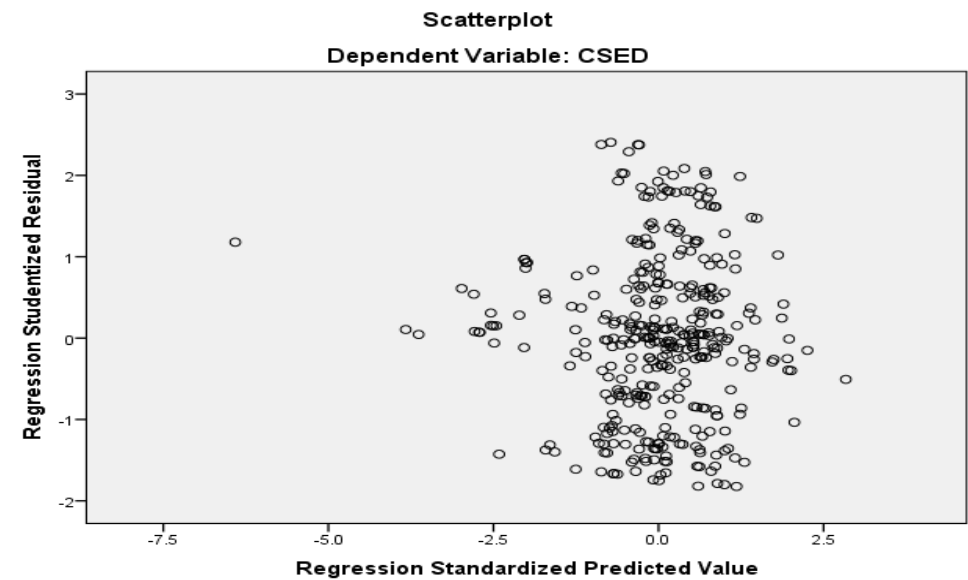

